\title{
Het consumentenrecht in de jaren negentig : een zware taak voor consumentenorganisaties
}

Citation for published version (APA):

Rijken, G. J. (1991). Het consumentenrecht in de jaren negentig : een zware taak voor consumentenorganisaties. Kluwer. https://doi.org/10.26481/spe.19911114gr

Document status and date:

Published: 14/11/1991

DOI:

10.26481/spe.19911114gr

Document Version:

Publisher's PDF, also known as Version of record

\section{Please check the document version of this publication:}

- A submitted manuscript is the version of the article upon submission and before peer-review. There can be important differences between the submitted version and the official published version of record.

People interested in the research are advised to contact the author for the final version of the publication, or visit the DOI to the publisher's website.

- The final author version and the galley proof are versions of the publication after peer review.

- The final published version features the final layout of the paper including the volume, issue and page numbers.

Link to publication

\footnotetext{
General rights rights.

- You may freely distribute the URL identifying the publication in the public portal. please follow below link for the End User Agreement:

www.umlib.nl/taverne-license

Take down policy

If you believe that this document breaches copyright please contact us at:

repository@maastrichtuniversity.nl

providing details and we will investigate your claim.
}

Copyright and moral rights for the publications made accessible in the public portal are retained by the authors and/or other copyright owners and it is a condition of accessing publications that users recognise and abide by the legal requirements associated with these

- Users may download and print one copy of any publication from the public portal for the purpose of private study or research.

- You may not further distribute the material or use it for any profit-making activity or commercial gain

If the publication is distributed under the terms of Article $25 \mathrm{fa}$ of the Dutch Copyright Act, indicated by the "Taverne" license above, 
Het consumentenrecht in de jaran

negentig: at zure mak

voor copsumentenorganisatie 
Tor mogdahtenis an minn owders

Aan Bramilde 


\section{Het consumentenrecht in de jaren negentig: een zware taak voor consumentenorganisaties}

Rede

uitgesproken bij de aanvaarding van het ambt van bijzonder hoogleraar in het consumentenrecht aan de Rijksuniversiteit Limburg te Mastricht op donderdag 14 november 1991

door

Mr. G.J. Rijken

Kluwer - Deventer - 1991 


\section{CIP-GEGEVENS KONINKLIKE BMBLIOTHEEK, DEN HAAG}

Rijken, G.J.

Het consumentenreche in de jaren negentig : en zware tak voor consumentenorgam nisaties/G. Rijken. - Deventer: Kluwer

ISBN 90-268-2217-0

NUGl 697

Trefw.: consumentenrecht.

Tekening omslag: Sander Rijken (10 jar")

(C) G.J. Rijken, 1991

Alle rechten voobchouden. Niets uit deze uitgave mag worden verveelvoudigd, opgestugen in cen geatomatiserd gegevensbestand, of openbaar genaakt, in enige vom of op cnige wijze, hetzij elektronisch, mechanisch, door fotocopiean, opmanen, of op enuge andere manicr, zonder voorafgande schriftelijke toestemming van de uitgever.

Voor zower het maken van koplect uit deze uitgave is toegestaan op grond van arti kel 166 Autcurswet 1920 jo. het Beshit van 20 juni 1974 , Stb. 351 , zoals gewijzigd bij het Beslut van 23 augustus 1985, Stb. 471 en artikel 17 Auteurswet 1912, dient men de dastroor wetteljk verschuldigde vergoedingen te voldoen an de Stichting Reproreche (Postbus 882,1180 AW Amstelven). Voor het overnemen van gededte(n) uit deze uitgave in bloemlezingen, readers en andere compilatiewerken (artikel 16 Auteurswet 1912) dient men zich tot de uitgever te wenden. 
Mijnheer de Rector Magnificus,

Dames en Heren,

\section{INLEIDINC}

De Consumentenbond heeft aan onze juridische faculteit een bijzondere leerstoel consumentenrecht gevestigd. Dat is een verheugend feit. Het consumentenrecht heeft zich in ons land in de afgelopen twintig jaar nagenoeg vanuit het niets ontwikkeld tot een autonoom functioneel' rechtsgebied. Een leerstoel consumentenrecht is daarvan een bevestiging. Het vestigen van deze leerstoel geschiedt op een cruciaal moment. Wij staan namelijk aan de vooravond wan de invoering van ingrijpende consumentenwetgeving. Deze wetgeving wordt gekenmerkt door hat dwingendrechtelijke karakter. Dwingend recht "verplicht", niet alleen ondernemers, maar voorall ook de consumentenorganisaties. Het zijn met name de consumentenorganisaties die in de jaren negentig de consumentenbescherming zullen moeten effectueren. We gaan interessante tijden tegemoet.

De Maastrichtse 'Regeling der inaugurale redes' houdt de orator voor de oratic zodanig in te richten, dat deze ook voor leken op het betreffende vakgebied begrijpelijk is. Dus weinig vaktechnische termen, geen 'geheimtaal'. Mij spreckt dit zeer aan. Het deed mij denken aan de rechtspraak van het Bundesgerichshof, waarin regelmatig bedingen in algemene voorwaarden nietig worden geoordeeld alleen al op grond van het feit dat de inhoud daarvan voor de Durchschnitsketude onvoldoende duidelijk is. Men noemt dat het Transparenzgebot. ${ }^{2} \mathrm{k}$ hoop dat de inhoud van mijn oratie die toets zal doorstaan.

\section{ENKELE VOORBELLEN VAN OONSUMENTENLEED}

Het consumentenrecht dient ter bescherming van de consument. Bescherming tegen wat? Om u daarvan een indruk te geven som ik een aantal - vrij willekcurige - voorbeelden van consumentenleed op.

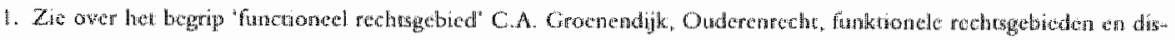



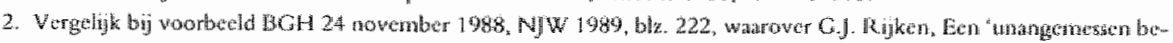


1989 , bla. $105-107$ 


\section{Onweilige produlden}

Een fles frisdrank van glas ontploft, ook zonder dat de lle door de consument wordt angerake, de rüt van een grill-bakoven springt, weeswaren bevaten nietjes, in een pot pindakars ziten spjkers, een glazen rasp lat bij gebruik stukjes glas in het eten acher, speelgoed heeft scherpe randen waraan kinderen zich gemeen snijden " Een baby-kruik lekt." Het slaapmiddel Hacion veroorzakt volgens de Halcion-slachtoffers onder meer de volgende klachen: ondragelijke hoofdpinen, geheugenverlies, panische angsten en zelfmoordmeigingen." Sommige DES-dochters krijgen, doordar hun moeders tijdens de zwangurschap het geneesmiddel DES hebben gebruikt, een bepalde vorm van kanker. Het Dalkonschildje, en anticonceptiemiddel, veroorzakt tenduzenden ernstige slachtoffers, soms met dodelike afoop. Enzovoorts, enzowoorts.

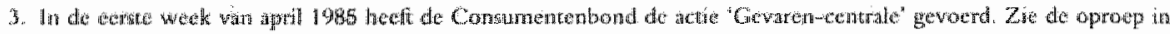

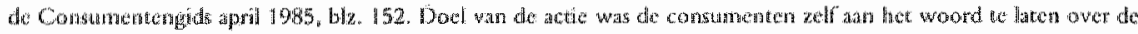

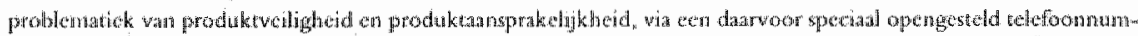

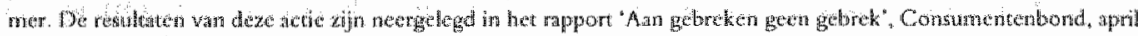

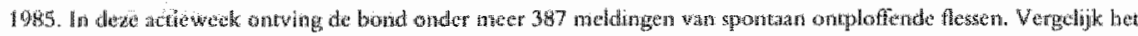
wolgendet ivereidint:

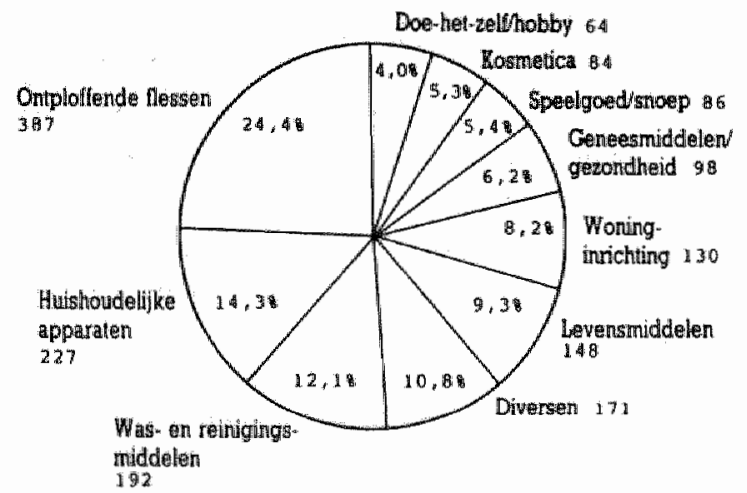

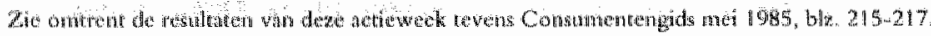

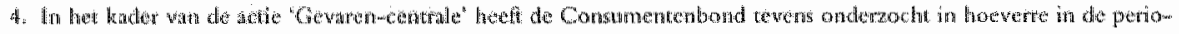

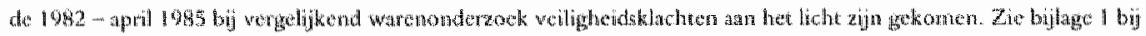
dexe orativ.

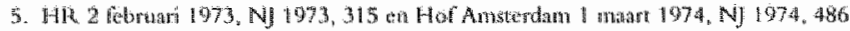

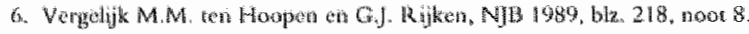

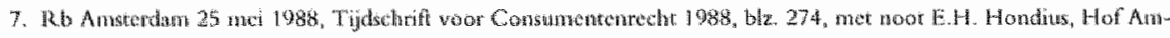

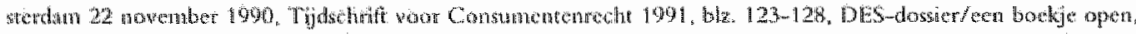

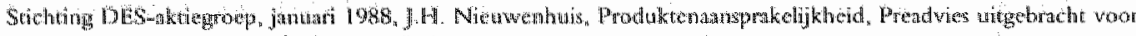



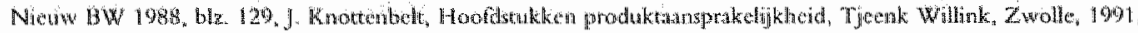
bla. 105.

8. J. Knotcenbet, a, w, b|z, 216, 217 
Ondenemers plegen sinds jar en dag in hu algenene (keverings-, reparate-, verkoop-, rets-, annemings-, huur-, etc) voowwarden recliten die de consument krachters het Burgerlyk Wetboek heeft, te beknotten en wettelyke ansprakelijkheden die op de ondememer rusten, te beperken of zels geheel wit te shiten. Zo kom men in algemene woorwaarden bij herhaling bedingen tegen in de trant wan:

- alle ambiedingen zijn vrijblijvend en binden ons nier;

- de overeenkomst wordt eerst geacht tot stand te zijn gekomen nadat wij deze schriftelijk an de consument hebben bewestigd;

- wiy behouden ons het recht woor de overeengekomen prijs te verhogen:

- de afgesproken levertijden binden ons net, zij zijn slechts bedoeld als een benadering van de nagestreefde werkelijke datum;

- elke verhindering on de overeenkomst (tijdig) uit te voeren, lavert ovemacht op;

- het is de consument niet toegestaan zijn betholigsverplichtingen op te schorten:

- het is de consument niet toegestan enig bedrang met het door hem an ons werschuldigide te verrekenen;

- het is da consument niet toegestan de overeenkomst te ontbinden;

- de consument moet ommiddellik na het constateren van het gebrek bij ons reclameren, op strafe wan verval van (alle) rechten;

- een (garantie)(lees: exoneratie)beding warin de ondememer zijn aansprakelijkheid beperkt of uitsluit voor nagenoeg alle denkbare schadeposten;"

- enzovoorts, enzovoorts. ${ }^{\text {it }}$



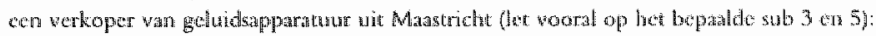

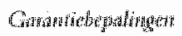

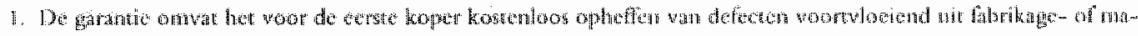
terialouter, bij ecti noriadal gebruik.



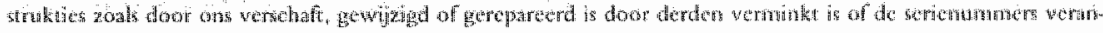

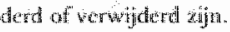

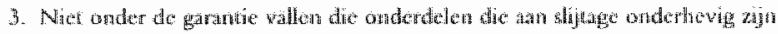

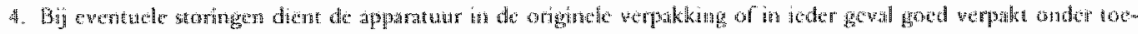

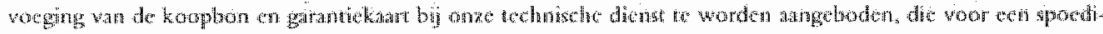

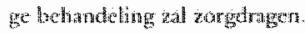

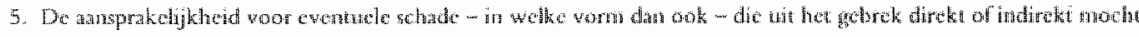

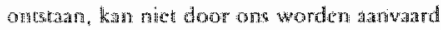

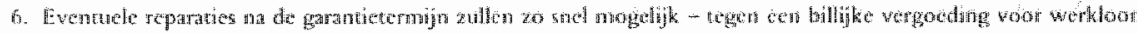

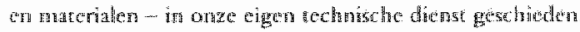

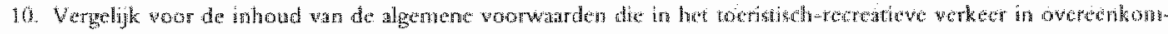

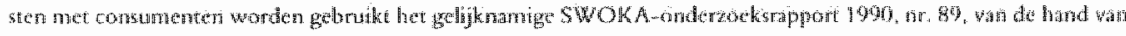

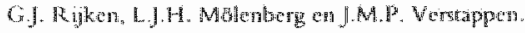


Ook dete bedrijstak kent gevallen van consumentenleed. Bij voorbetd: een reisbureau/resorganisator tallicent wardoor u de - door u woonitbetalde - reisbijetten niet ontwangt, en bhjk cen foutreve (te lage) prisanduiding in de reisgids te stam, de vhegres ondervindt vertraging, ww bagage is werdwenen, door overboelking van het hotel (circa 66.000 gevaller per jaat) kriggt th de togezegde hotelkander net, de hygienc is stecht, gev witcht op ze, het ligbad blikt niet anwezig de hostess is on


zathent.

\section{Andere bedriffakken}

Ook in (alle) andere bedrifstaken doen zich dergelijke consumentenproblemen voor. Er zin niet voor niets recdis geschillencommisses opgericht voor Chemisch Reinigen, Natwas, Reizen, Recreatie, Woninginnchting, Parket, Keukens, Openbare Nutsbedrijven, Bankzaken (Postbank), Post en Telecommunicatie, Optick en Uitwartwezen. De Stichting Geschillencommissies voor constmentenzaken makt ecn explosieve groei door." Toch bliff de marktekking van de geschillencommissies nog steeds beperkt:

Een zak die zich recentelijk in de Horeca heeft voorgedan, vind ik zó schiterend, dat ik u deze - als voorbeeld wan (verholpen) consumentemleed - niet kàn onthouden.

Het bruidsparr Vam Gijtenbeek en Soek wil de huwelijksnacht doorbrengen in de 'Imperial Sute' van hat bekende Hagse Hotell Des Indes. Op 13 mart 1990 word deze rumte gereserveerd voor de nacht van zaterdag, 2 juni 1990. Nadien verhuunt Des Indes de 'Imperial Suite' alsmede de derde etage van het hotel woor de duur wan negen dagen (waronder de bewuste nacht) an de Amerithanse popster Prince on zijn govolg. Begin mei 1990 deelt Des Indes an het bruidspar mede, dat de "Imperiall Suite' op zaterdag, 2 juni 1990 , net voor teze beschkbar is. Het bruidspar wil voor Prince nick wijken en vordert in kort geding van de exploitante van Des Indes makoming van do tussen then gesloten owereenkomst. Ten processe wordt door deze explointe con berocp gedam op de zogenoende "dubbelboekingselausule" in de

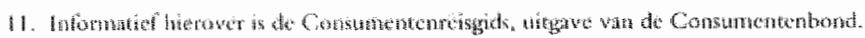

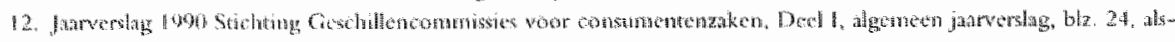

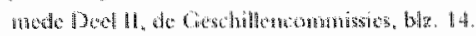



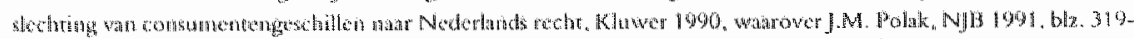

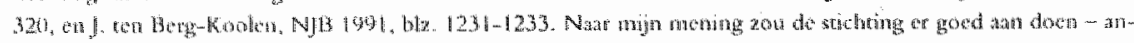

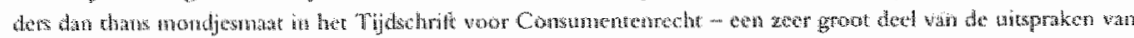

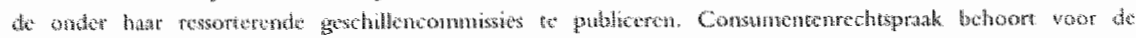

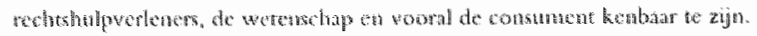


toepasselijke Unitome Voomaarden Federatie Horeca, Ludende: 'De hotelhouder is gerechtigd on wan de gast te verlangen dat deze andere accommodatie geleverd krijgt dan volgens de horeca-overeonkomst geleverd zou moeten worden'. M.a.w.: het bruidspar moet mar genoegen nemen net een andere kamer. Dg Haago President makt korte metten met het beroep op deze clausule. Uit de motivering van de Pre sident citer ik het wolgende:

3.17. (...) Het streven van de hotehouder zal er in de eerste plats op gericht behoren te zijn de overeenkomst met de gast volledig na te komen. Zo hebben wisers ar rech op, dat de hotelhouder alles in het werk stelt om de overenkomst na te komen en allex vermijt dat die nakoming zou kumen verhinderen. De hotehouder zoals gedaagde, die verkicst hter met een ander te contracteren, komt zijn primaire verplichting jegens de exrste contractant niet na: zo'n hothouder werliest het recht van de gast te verlangen genoegen to nemen met een verwangende prestatie',

alsmede

3.19. Voor dat geval geeft art. 5.8 de gast het recht de overeenkomst onmiddellijk te beaindigen. Anders dan gedaagde heef beroogd sluit deze voor de hand liggende bevoegdheid voor de teleurgestelde hotelgast net de gebruikmaking van zijn primaire recht op nakoming uit."

De President legt mitsdien het accent op het recht op nakoming, oordeelt dat de dubbelboekingsclausule dat recht niet uitsluit en wijst vervolgens de vordering (net een dwangsom van $\left.f 25.000_{n}-\right)$ toe. ${ }^{4} \mathrm{Na}$ een dergelijke rechterlijke uitsprak plegen ondememers hun woorwarden te wijzigen. In casu zou dit in dier" voege moeten gebeuren dat het recht op nakoming met zoveel woorden wordt uitgesloten. In dat geval zou echer het neuwe consumentenrecht een dergelijke anpassing van de voorwaanden rechtens blokkeren. Bedoeld beding zou immers 'zwart' zijn op grond van art. $6: 236$ sub a NBW en dus zonder mecr vernictigbaa!

\section{Agressueve handelopraktijken}

Veel consumentenled word voorts verooraakt door agressieve handelspraktijken die zich in vele vormen en gradaties van agressivitet aandienen. Dentk bij voorbecla aan colportage ("huis-aan-huis", schriftelik, telefonisch, enzovoorts), misleidende reclame, pyramideverkoop, cadeasystemen, mislcidende prijsergeliking, brieventusreclame, huissampling (gratis verspreiden van monsters van produkten), incrtia selling

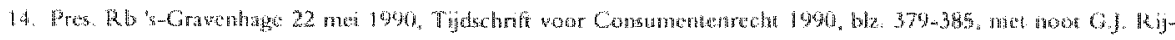
ken. 
(ongewragd toezenden var goederen), sweepsakes (prijzenfestivals). verkoop-

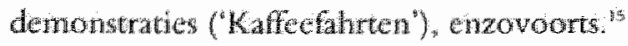

Toi zover endele voorbedden van consumentenleed. Het werkterten wan het consumentenrecht is echter armerkelijk omvangrijket dan de gegeven voorbeelden zullen doen vermoeden. ${ }^{1 x_{3}}$

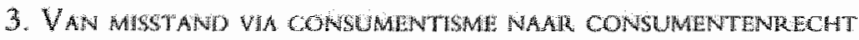

In de worige paragraf hebben we onder meer gezien dat ondernemers door middel van het gebruk wan algemene voorwarden de consumeth als het ware buiten de werking wan het Burgerijk Wetboek platsen. De consument als contractant is nagenoeg rechteloos: Mag dat zomarr Ja, in beginsel mag dat, want het Burgerlik Wetboek van 1838 geeft - later ingevoerde aanvulingen ter bescherning varn bij voorbeeld de werknemer, de huurkoper en de huurder van woonnumte weggedacht - regels van regelcnd recht. De contractsvijheid brengt mee dat in een overeenkonst van het wettelijk regelend recht mag worden afgeweken, dus ook met behulp van algemene woorwarden. Gras stelt terecht dat de contractswijheid in naam van de contractswijheid is teruggedrongen." Bezien vanuit de positie van de consument is er geen contractsulijheid, geen mogelijkheid om de inhoud van de overeenkomst mede te bepalen. "U contracticert op onze woorwaarden of u contracteert niet". Een dergelijke 'take it or leave it'-situatie is de juridische werkelijkheid voor onze consument. Mara dat is toch een misstand? Natuturlik! In zijn dissertatie kwalificeert Hondius het enkele bestan van onredelijk bezwarende bedingen in algemene voorwatrden als "misbruik in rume zin" en in zijn preadvies van 1979 voor de Nederlandse JuristenVereniging sprekt hij in dit verband van een 'misstand". Hoe kon die misstand ont-



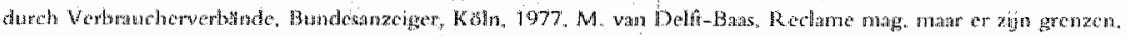

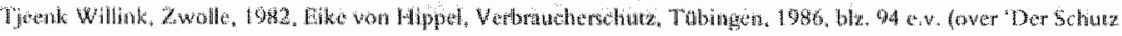

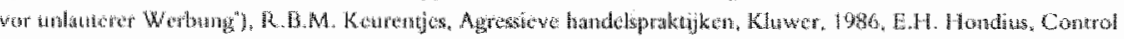

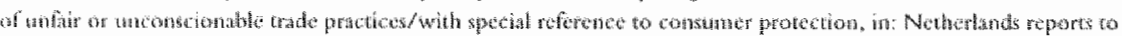



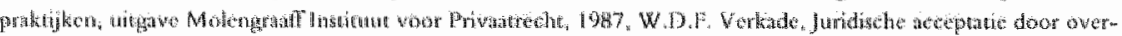

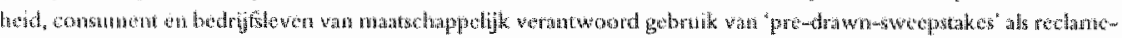

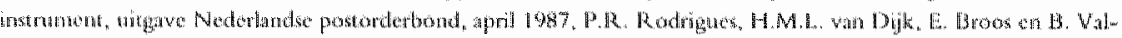

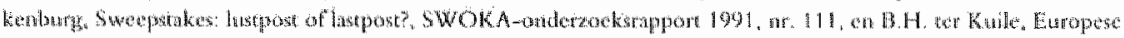

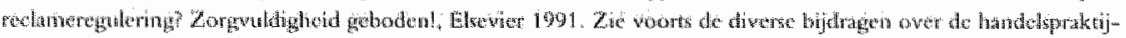

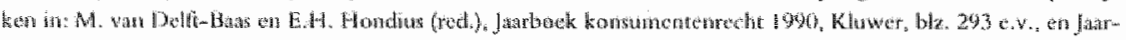

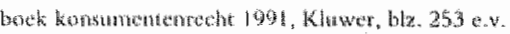

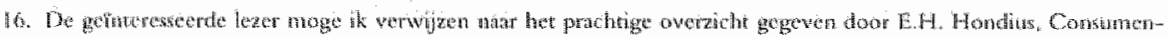

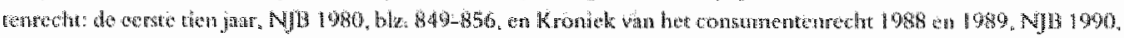

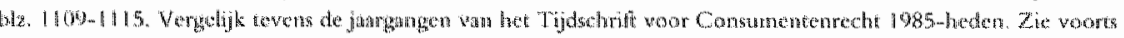

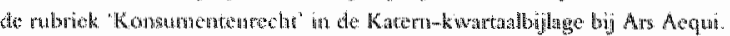

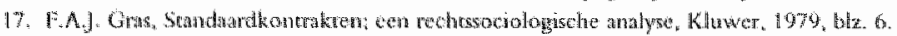




stan? Was onze wetgever van 1838 dan met in stat en deugdelgk wetboek re ontwerpen? Wel degelikk Ons Burgerlyk Wetboek van 1838 gaf woor de tocnmalige voomamelik ambachtelike samenleving en evenwichtige regeling, althan woor hen die uberlaupt wat te contracteren lidden. In de optick wan onze wetgever wan 1838 stonden twee individuen als gelikwardige contractsartjen tegenover elkar. "Dit latste is sedert het einde van de vorige eeuw grondig veranderd. Denk and de industrialisatie mer de darmee gepard gaande massa-produktie en dus veel contracten en dus het gebruik wan algemene voom arden ${ }^{\text {za }}$

De ambachesman wordt een Gabrick. Het bedrif wordt gexpoloiteerd in NV-of BVvorm. De consument ziet zich als contractant geplaatst tegenover een economische en/of juridische machtspositie van de ondememer. ${ }^{21}$ Er is geen sprake meer van gelijkwaardige contractspartijen. Het Burgerlijk Wetboek van 1838 is - uitzonderingen als eerder genoemd dargelaten - echter nog steeds van regelend recht. Dart verklaart warom de ondernemer in stat is de consument buiten de werking van het Burgerlijk Wetboek te plaatsen.

In de jaren vijftig/zestig ontstatat in ons land, in navolging van internationale ontwikkelingen, een beweging die we nu anduiden met de term consumentistwe ${ }^{2 a}$ Deze bew weging wordt gevoed door de gedachte dat de consument invloed behoort te hebben op de kwaliteit van goederen en diensten, op de inhoud wan algemene vootwaarden, enzovoorts. Van Driel spreekt in dit verband van de ontwakunde consument: ${ }^{23}$ Met het consumentisme zien we de opkomst van consumentenorganisaties, ${ }^{24}$ In de jaren zeventig vinden de consumentenorganisaties en gewillig oor bij de overheid. Het past geheel in het denken in termen van een verzorgingsstat. In 1974 wordr in ons land een Interdepartementale Coördinatiecommissie voor Consu mentenzaken (ICC) opgericht ${ }^{25} \mathrm{Op} 14$ april 1975 neemt de $\mathrm{R}$ aad wan Ministers met het Eerste programma van de Europese Gemeenschap voor een beleid inzake bescherming en voorlichting van de consument' een resolutie an watrin ecn vijftal fundamentele rechten van de consument centraal staat, waaronder het recht op be-

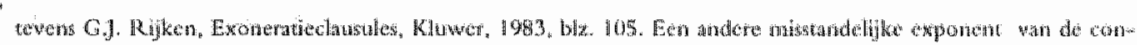

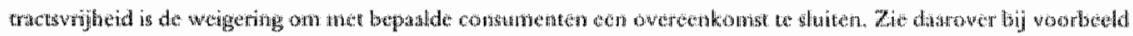

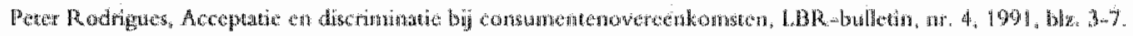

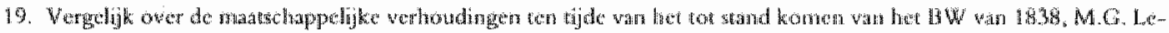

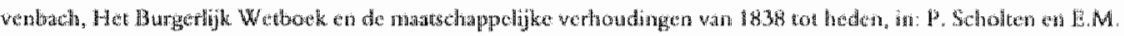

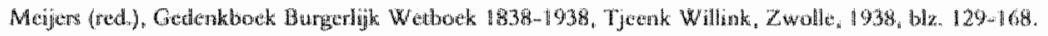

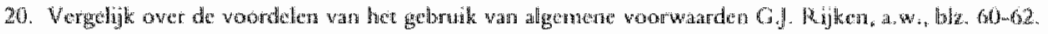

21. G.j. Riker, aw. biz. 156-165.

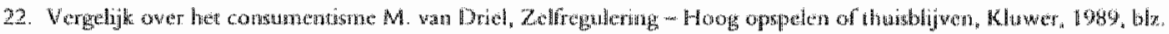

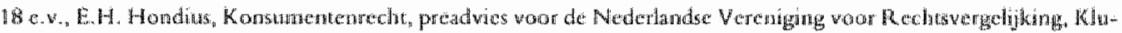

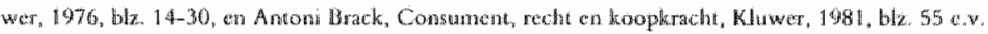

23. M. wan Drict, aid w, biz. 19

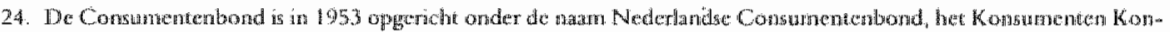

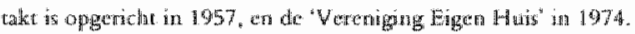

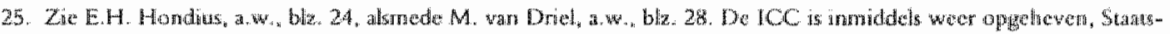
comrant 26 nos 1987 , nir. 99
} 
scherning van gezondheid en veiligheid alsmede het recht op schadevergoeding. ${ }^{36}$ Deze ontwikkeling leidt in de jaren tachtig tort een wetgevingsgolf in Europa ter bescherming van de consument. In de jaren negentig komen we in de fase dat de actoten in het rechtsbedrijf in ons land met deze wergeving zullen moeten werken - de effectueringsfase.

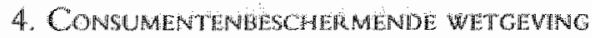

Aan welke wetgeving moeten we zoal denken? Ik geef enkele voorbeelden ${ }^{27}$

\section{Produkteriansprakelijkineid}

Op 1 november 1990 is in ons land ter uitwoening van een desbetreffende EEG-richtlijn ingevoerd een wettelyke regeling van de produktenaansprakelijkheid, de art. $1407 \mathrm{at} / \mathrm{m} \mathrm{j} \mathrm{BW.} \mathrm{Met} \mathrm{deze} \mathrm{regeling} \mathrm{beoogt} \mathrm{men} \mathrm{de} \mathrm{consument} \mathrm{te} \mathrm{beschermen} \mathrm{te-}$ gen de schadelijke gevolgen van onvelige produkten. Aardige elementen wit deze regeling zijn dat op de producent een aansprakelijkheid buiten schuld wordt gelegd (art. $1407 \mathrm{a}$ BW), het uitgebreide antal producenten (onder omstandigheden is ook de winkelier producent in de zin van de wet) (art. $1407 \mathrm{c}$ leden 2-4 BW) en dat de producent zijn aansprakelijkheid niet jegens de benadeelde consument kan uitsluiten of beperken (art. $1407 \mathrm{~h}$ lid $1 \mathrm{BW}$ ). Minder geslaggd acht ik de vervaltemijn van 10 jaar en de verjaringstermijn van 3 jaar (art. $1407 \mathrm{~g} \mathrm{BW}$ ). Door deze korte vervaltermijn worden sommige slachtoffers van onveilige produkten - zoals de DES-dochters - van een beroep op deze regeling afgesneden. De schadelijke gevolgen van het DES-middel openbaren zich bij de DES-dochters namelijk eerst gerume tijd na de 10 jaar na het in het verkeer brengen van het onveilige produkt. Gelukkig heeft het Gerechtshof Arnhem in de Halcion-zaak laten zien dat ook op de grondslag van art. $1401 \mathrm{BW}$ een zelfue bescherming kan worden geboden - ik kom daar straks op terug - maar het is een slechte zaak dât die weg moet worden gevolgd. De regeling van de art. 1407a-j BW wordt per 1 januari 1992 opgenomen in de art. 6:185 t/m 6:193 NBW.

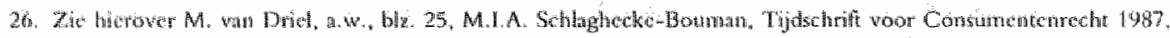

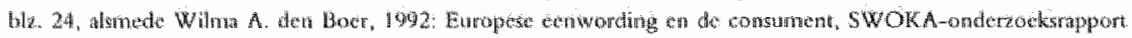

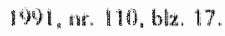

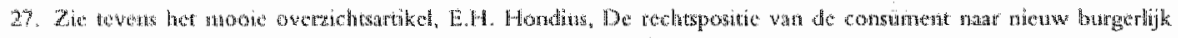

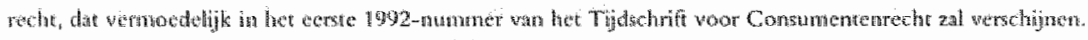

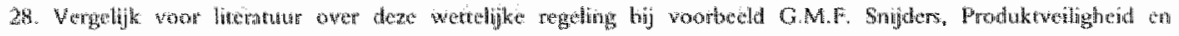



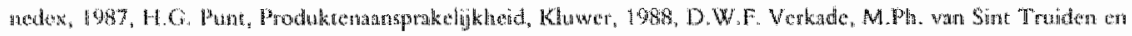

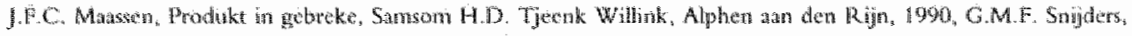

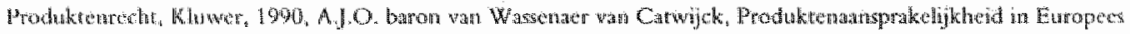

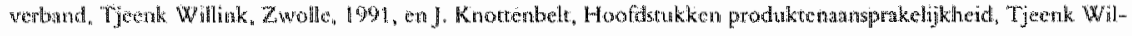
Iunth, Zwalle, 1991 
Op 1 januari 1992 kent onze wetgeving een regeling van de consumentenkoopovereenkomsten in titel 7.1 NBW ${ }^{2}$ Deze regeling geef de oonsunent-koper cen antal rechen jegens de verkoper die hem een ondeugdeljke, niet an de overeenkonst beaniwoordende zatk levert. Bij voorbeeld de bijzondere acties van art: $7: 21$ (recht op aflevering wan het ontbrekende, reche op herstel, mit.... recht op verwanging, ten zij...) en via art. $7: 22$ de algemene rechten en acties uit de boeken 3 en 6 (wilsgebreken, opschorting, verrekening, enzovoorts). Voor het recht op schadevergocding was in verband met de wettelike regelng van de produktenansprakelijkheid ten apart artikel (7:24) nodig, omdat de wetgever de verkoper behoudens enkele uitzonderingen niet aansprakelijk wilde doen zijn voor "produktschade". De regeling van de consumentenkoop is van dwingend recht. Titel 7.1 NBW zal de middenstanders (-verkopers) net onberoerd laten. Men zal de consument-koper niet langer kwinen afschepen met uitspraken als 'ik zal overleg moeten plegen met de fabrikant' of 'kijk maar wat in ons garantiebewijs stat".

\section{Algewene woorwataden}

Een nog veel groter effect op het contractuele handelen van ondenemers zal de wet algemene voorwarden (afd. $6.5 .3 \mathrm{NBW}$ ) hebben, eveneens van kracht per 1 januari 1992. Bijna alle ondernemers hanteren ook in overeenkonsten met consumenten algemene voorwarden (woninginnchters, loodgieters, anmemers, architecten, reis organisatoren, chemische wasserijen, garagebedrijven, glaszetters, autoverhuurders, garderobe-exploitanten, banken, makelaars, hotehouders, postorderbedrijven, vethuurders van zonnebanken, exploitanten van autowasserettes, verzekeraars, explötanten wan jachdhavens, campings, sport- en fitmess-scholen, opticièus, reparateurs, luchtvaartmatschappijen, enzovoorts, enzovoorts), Zij allen zullen moeten leren leven met vooral de volgende twee elementen uit de wet algemene voorwarden.

Ten eerste de informatieplicht als bedoeld in art. 6.233 anhef en sub bo ant 6.234 NBW. In de meeste gewallen zullen de ondernemers hun algemene voowarden voor of biy het sluten van de overeenkomst aan de consument - letterlijk - moeter



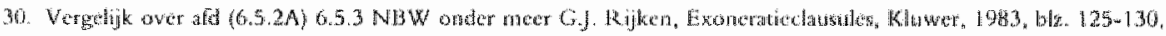

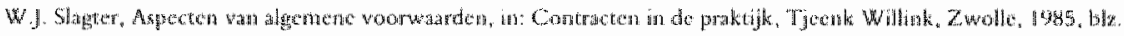

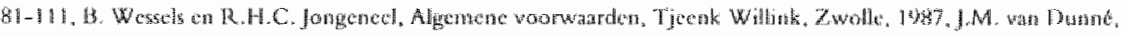

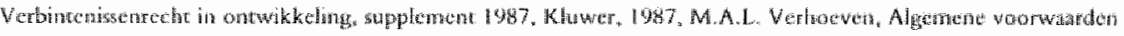

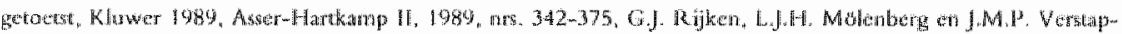



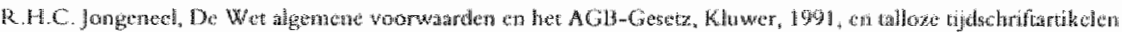

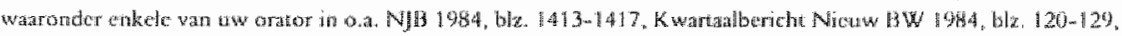

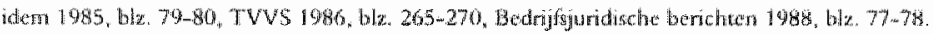


ter hand stellen, op straffe wan wemietigbaatheid wan alle bedingen in de algemene voorwaten. Hier wordt radicall gebroken met de hudige prakujk van vershnering wat betreft de wijze van incorporatic wan de algemene voorwarden. Ondememer worden op dit punt tot openheid gedwongen, die zij - althans zeer velen - niet gewend zijn te geven. Dit zal de nodige aanpassingsproblemen geven.

In de weede plats de inhoud wan de bedingern in algemene voorwarden. Consumenten krijgen de bevoegdheid deze bedingen (butengerchtelijk) te vemiengen, indien deze jegens de consument onredelijk bezwarend zijn (art. 6:233 amhef en sub a NBW). Ter bevordering wan de rechtszekertheid geeft de wetgever in art. 6.236 NWW ech opsomming van bedingen die in owereenkomsten met de consument ats onredeligk bezwarend worden angemerkt. De zogenaande "zwarte lijst". Voorbeelden van 'zwarte' bedingen: uitshiting van het recht nakoming te vorderen (sub a). untshluting of beperking vain de ontbindingsbevoegdheid (sub b), uitshing of beperking wan opschorting bevoegdheid (sub c), prijswerhoging binnen drie manden na het sluiten wan de overeenkomst zonder de bevoegdheid te geven in dat geval de overecrkomst te ontbinden (stub i), enzovoorts. Daamast geeft de wetgever in art. 6.237 NBW ecn 'grijze lijst'. Sommige bedingen in algemene voorwaarden, zoals de exoncratieclausule (sub t), worden pernoed in overeenkomsten met consumenten onredelijk bezwarend te zijn. Over deze 'grijze' bedingen bestaat - nar mij is gebleken - in ons land het wijdverbreide misverstand dat het met die bedingen 'niet zo'n vart zal lopen'. Bedoeld wettelijk vermoeden brengt mee dat de "grijze' bedingen 'zwart' zojin zolang niet door de gebmuker van deze bedingen is gesteld en bewezen dat deze in de voorliggende casus nict onredelijk bezwarend $z$ injn. De "grijze bedingen zijn in hun praktische uitwerking dus niet 'grijs', maar 'zwart met een wit randje". Daar ligt een. belangrijk accentverschil. Deze wet algemene voorwaarden laat op prachtige wijze zien hoe de wetgever met een dwingendrechtelike (art. 6:246 NBW) regeling een instrument biedt om het juridische evenwicht tussen de met elkar contracterende ondernemer en consument, welk evenwicht onder de werking van het Burgerlijk Wetboek wan 1838 door de veranderde maatschappelijke en juridische verhoudingen sedert het einde wan de vorige ceuw ernstig is verstoord, te herstellen.

Tot fover ecn summiere belichting van ankele voor de consumentenpraktijk hoogst belangrijka produkten van consumentenwetgeving. Men zij erop bedacht dat er meer voorbedden zijn, zoals de Wet beperking cadeaustelsel (1977), de Colportagewer (1973, laatstelijk gewijzigd in 1989) en de Wet op het consumentenkredict" (van kraclat peir I jonumi 1992).

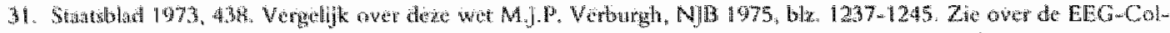

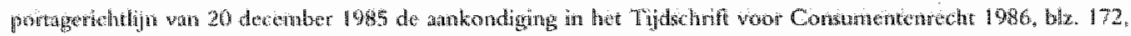

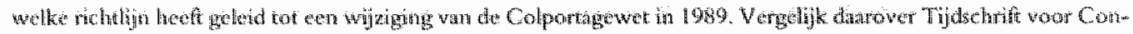

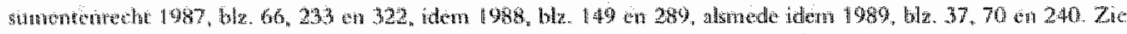

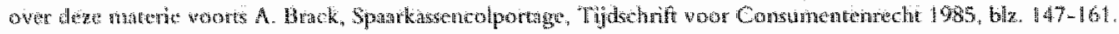

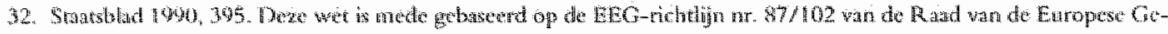


Bovendien stat nog een aratal wettelike regelingen in de steigens. 20 bij woorbedd

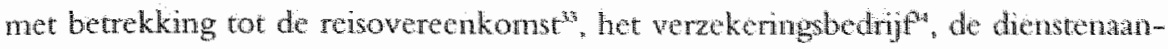
sprakelikheid", de consumentenkoop van orroerend goed ${ }^{3 i}$, de geneeskundige

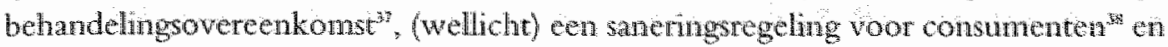
de 'Nieuwe Aanpak' -richtlingen."

\section{MeER WETGEVING ZAL NODIG BUIJEN: TWEE VOORBLELDN}

Het is inherent an thet consumentenrecht, an de wens on de consument te beschermen, dat zo nu en dan opnieuw de hulp van de wetgewer ingeroepen zal moeten wor den. Ik geef wee voorbedden.

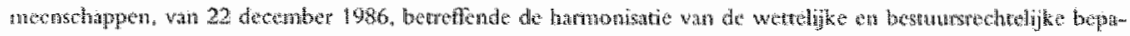

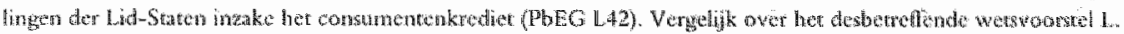

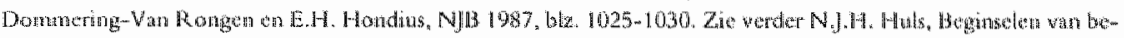

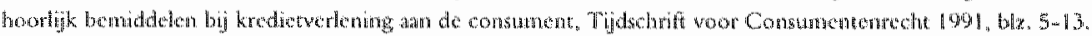

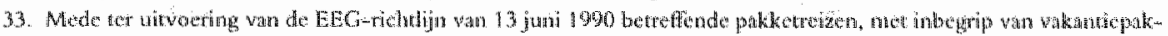

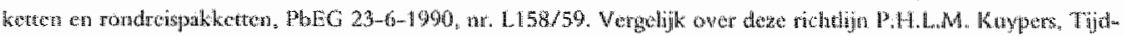

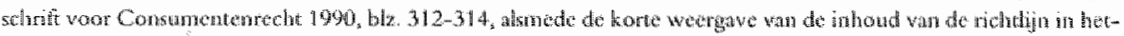

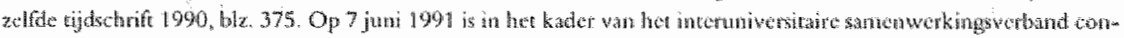

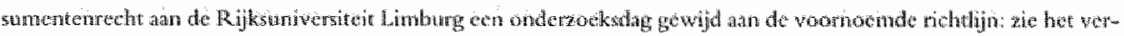

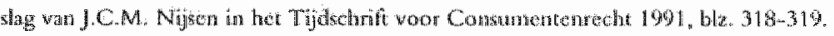

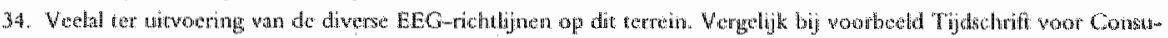

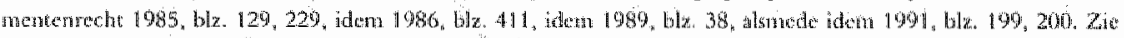

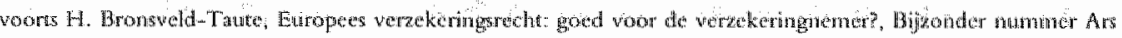

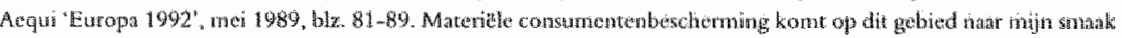


distigend verient?

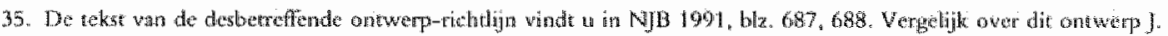

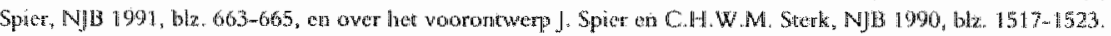

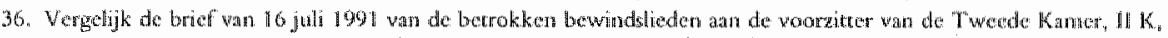

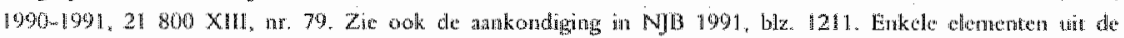

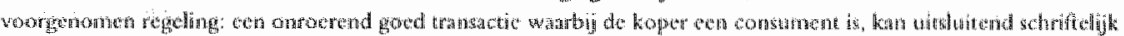

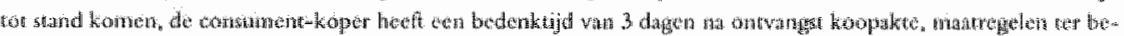

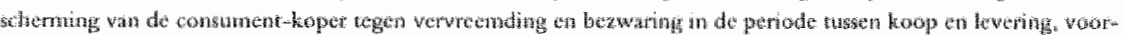

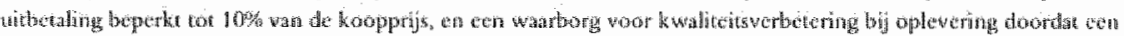

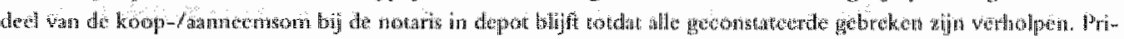

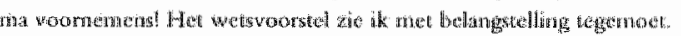

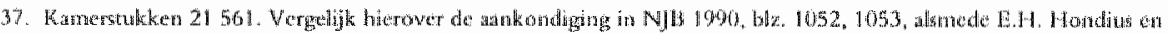

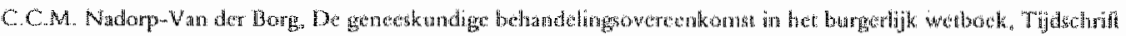

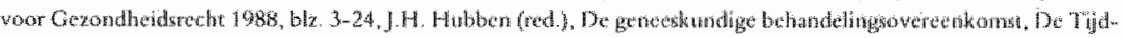

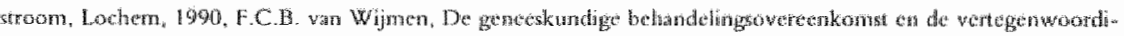



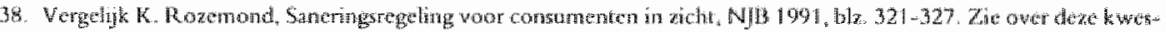

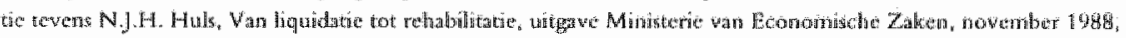

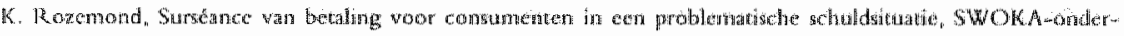

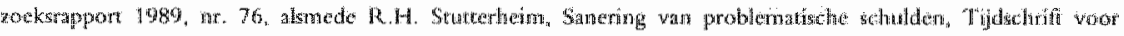
Consumentereche 1091, biz. $14-23$

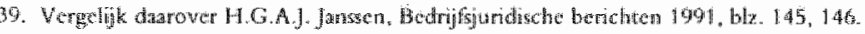


Het DES-hormoon is in Nedertand in de periode van $1947-1975$ voorgeschreven arn zwangere vrouwen, meestal om een miskram te vookomen. Bij 1 op de 1000 DESdochters blijkt zich een schadelijke bijwerking voon te doen: clear-cell-adenocarcinoom (kanker in de baamoederhals en de vagina). Deze vorm van kanker openbaart zich bij de DES-dochters voomamelijk tussen hun $14 \mathrm{e}$ en $21 \mathrm{e}$ levensjaar. Naar schatting kent Nederland zo'tn 55 DES-slachtoffers. Enkelen wan hen zijn inmiddels overleden." Zes DES-dochters hebben een vordering tot schadevergoeding ingesteld tegen tieri Nederlandse producenten wan DES. De Amsterdanse rechtbank en in hoger beroep het Ansterdamse hof hebben de vordering afgewezen."

De watk is momenteel bij de Hoge Raad aanhangig. De DES-dochters hebben een bewijsprobleem. Zoveel jaren (14 tot 21 jaar) nadat hun moeders het DES-middel hebben gebruikt, is natuurlijk niet meer te achterhalen van welke producent het DESmiddel afkonstig was dat in elk specifick geval de andoening heeft veroorzaakt. De rechtbank overweegt in dit verband:

3. In hun werweer hebben gedaagden aangevoerd dar (..) geen wan gedaagden geïdentificaerd kan worden als degene, die de DES-tabletten, die de moeders van eiseressen mogelijkerwijs hebben gesikt in het verkeer heeft gebraclat en evenmin kan worden vastgesteld dat de betreffende DES-tabletten in ieder geval wan eén van de gedagden afkomstig zijn. Gedaagden hebben in dat verband onweersproken gesteld dat in 1963 in ons Jand 200 farnaceutische fabrikanten, 9 erkende farmaceutische groothandelsbedrijven, 37 erkende grossiers en 880 apothekers gevestigd waren en dat ieder daaryan DES, waarvan de grondstof vrijelijk werkrijgbaar was, in het verkeer kan hebben gebracht."

De DES-dochters doen ten processe onder meer een beroep op art. 6:99 NBW -- ten aanzien waarvan het hof oordeelt dat dit artikel een rechtsregel geeft die ook voor het huidige recht als geldend moet worden aanvaard ${ }^{42}-$, luidende:

'At. 99. Kan de schade een gevolg zijn van twee of meer gebeurterissen voor elk warvan ech andere persoon arasprakxlyk is, cn stat wast dat de schade door ten minste én van deze gebeurtenissen is ontstan, dan nust de verplidnting om de schade te vergoeden op ieder wan dewe personen, tenzij hij bewijgr dat deze niet het gewolg is van een gebeurtens watrwoor hijgelf ansprakelijk is."

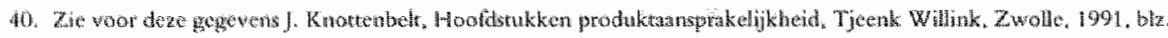

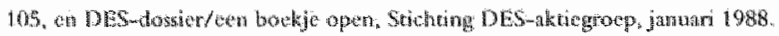

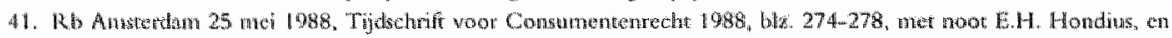

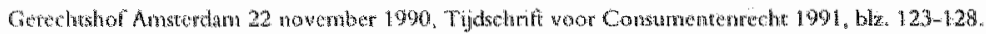

42. 7 in not an! 
Rechtbank en hof wizen een beroep op dic artikel af. De rachtbank kont op grond van een wetshistonsche interpretacie tou de conclusie:

(...) dat, wil er sprake zijn van een dergelijk onkering wan de bewghsto, not watsan dat de dader behoort tor de dansprakellik gestelde personen. Dite wastatelling is onmogelyik ats de schade, zoals in deze zaak, ook het gevolg kan zijn wan do daad van een niet watusprakelijk gestelde persoon."

Het hof oordedt dat voor toepassing van art. $6.99 \mathrm{NBW}$ in elk geval vereist is dat cxact wordt gesteld en vervolgens ook komt vast te stan wie tot de kring der ansprakelik te houden personen behoort, nu de in concreto geleden schade antoonbaar het gevolg moet zijn van temingte edn van twee of meer specifek te stellen on zonodig te bewijzen gebeurtenissen in de zin van art. 6.1.9.4a NBW". De DES-dochters hebben niet aan de vereiste stelplicht voldaan:

'Indien daarwoor niet reeds uit processueel oogpunt bezien noodzakeljk is on alle pleggrs van die onrechtmatige dad zonder uitzondering in rechte te berreken, dan geldt in th gevall dat appelianten niet aan een stelplicht als herboven bedoeld hebben voldam en ook niet kunnen voldoen, nu zj erkennen dat de kring van degenen, die DES tn de te dezen relevante periode in her verkeer (kumen) hebben gebracht, groter is dan clie van de gezamenlijke geintimeerden zonder dat zij (kunnen) weten whe allenal in de relevate periode tot genoemde kring behoorden.

Zulks betekent dat, nu appellanten toegeven dat zij niet kunmen aangeven, laat staan bewijzer, dat de gestelde schade (in elk geval) (telkens) is teweeggebracht vanuit cen uitputtend an te geven kring warn personen, die DES in het verkeer heeft gebracht, zich daamee nier naar de eis van meergenoemde rechtsregel laat vaststellen door we'lk complex van "gebeurtenissen" de gestelde schade temminste is ontstaan."

lk verwacht dat tegen deze uitleg van art. 6:99 NBW een cassatiemiddel zal zijn gericht. Merig auteut houde deze witleg voor onjuist. Her wachten is nu op de uitspraak van de Hoge Rat. Mare wat als de Hoge Raad liet cassatieberoep verwerpt? Denkbar is natuurlik dat andere DES-dochters een procedure starten, watrin alle her bekende Nederlandse DES-producenten worden gedaguard en de zaak ook overi-

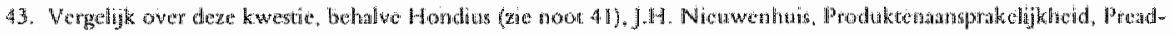

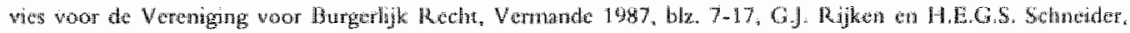



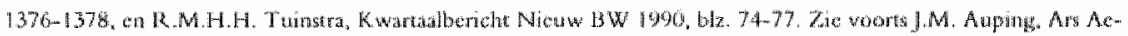

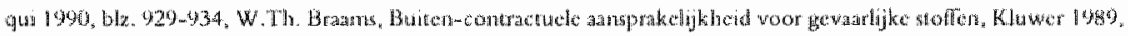

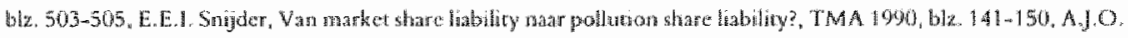

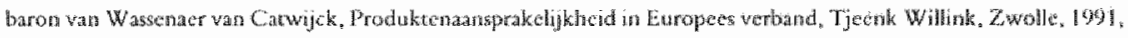

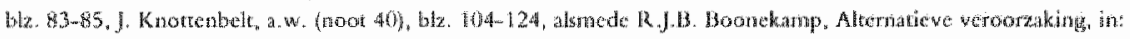

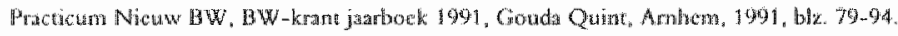


gens beter wordt opgezet on onderbouwd dan in deze lopende procedurc. Maar ook dan is - eigen aan een gerechtelyke procedure - succes niet verzekerd. Het word mijn inzien tijd dat de wetgewer ingrjpt. Het geval wan de DES-dochters is te schrijnend om pasiof te kumen bliven. Nieuwenhuis heef in 1987 in 2 inn preadwies voor de Vereniging wor Burgerligk. Recht een auntal condwstes geformuleerd, die waliswar haaks stan op de uitleg wan rechtbank en hof in de voomoemde DES-zaak, malar dic zich witstekend lenery woor cen verdang in een rieuw artak 6:99 NBW.

\section{Schadeafuikelingsburean Conswmentenzaken}

In thet dagblad De Limburger las ik recentelijk de volgende berichten.

4. De Surinamse Luchtvartmatschappij (SLM) zal maximaal 58.000 dollar (bijna 124.000 gulder) per slachtoffer uitkeren aan nabestanden wan de wliegramp in Suriname. De hoogte van dit bedrag is gebaseerd op het Verdrag wan Warschau. Volgens de advocat van SLM doet de maximale aansprakeliykheid niets af an het feit dat eerst bekeken moet worden whe reche hebben op een schadevergoeding.

b. "Mill Vanilli-platen: niet goed, geld terug". De miljoenen kopers van elpee"s, compart discs en cassettebandjes van het duo Milli Vanilli dienen elk een schadevergoeding van I tot 3 dollar te kijgen. Dit, ondat Mill Vanilli de onder deze naam uitgebrachte muzick niet zelf heeft ingezongen. De platenmaatschappij Arista en de Amerikanse vertegenwoordiger Bertelsmann Music willen een fonds van 250.000 dollar stichten voor drie organisaties die de klachteri van de platenkopers moeten bundelen. ${ }^{45}$

Nog twee voorbediden.

c. In de jaren 1960-1962 kenden we de Softenon-aftare. Duizenden baby's kwamen nuisvornd ter wereld doordat de moeder tijdens de zwangerschap het slaap- en kalmeringsmiddet thalidomide had gebrukt. In het toenmalige West-Duitsland was het middel onder de nam Contergan beschikbaar. In 1970 stelde de frma Chemie-Grünenthal GmbH tegen finale kwijting 100 miljoen mark plus rente beschikbar voor de circa 2.300 Duitse Contergan-slachtofers. De West-Duitse overheid wulde dit bedrag met 100 miljocn mark an, doch eiste dat deze bedragen zouden worden ondergebracht in een stichting voor hulpvertening an het gehandicapte kind. Dit werd bij wet geregetd: das Gesetz uber die Errichtung ener Stifung "Hilfswerk für behinderte Kinder" van 17 decomber 1971 . 4h



45. De dimburger, 30 aususcus 1991 .

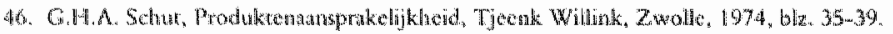


d. De Dalkon-zaak. De producent van het Dalkonschildje, A.H. Robus Company te Richmond (Ver. Staten), heeft ten behoeve van de crea 300000 shathofers een bedrag wan 2,5 miljard dollar ondergebiacht in de Dalkon Shicld Glamme Trust die voor de afwikkeling van de clams zorg draggt ${ }^{47}$ Circa 1.500 Nederlandse slachtofers hebben hun clam met hulp van de Consumentenbond ingediend. Inniddels hebben circa 950 Nederlandse vrouwen schadevergoding ontwangen.

\section{Wat hebben deze woobeelden met elkar gemeen?}

- Een wastande verplichting tot schadevergoeding op grond wan wanprestatie en/of onrechtmatige daad.

- Een groot antal personen dat recht heef op schadevergoeding.

- Vastgesteld moet nog worden wie recht hebben op schadevergoeding.

- Vastgesteld moet nog worden welk bedrag aan schadevergoeding dient te worden uitgekeerd.

Voorts spreekt uit enkele van deze voorbeelden de behoefte om de solvadeafwikkeling zoveel mogelijk buten het rechterlijk apparat om ter hand te nemen. Mij spreekt dit zeer aan. Het consumentemrecht dient vootal ook doelmatig te zijn en te blijen. Ie moet er toch niet aan denken dat bij woorbeeld de Dalkon-zak zich woor de Nederlandse rechter zou hebben afgespeeld en de schadeafwikkeling via de "schadestatoprow cedure' (art. 612 e.w. Rv) zou moeten platsvinden. ${ }^{4}$ Dat zou de rechterlijke macht onnodig zwaar belasten en stelt de schadeplichtige (rechts) persoon woor te vemijden proceskosterveroordelingen. Ik zou er dan ook wed voor woelen voor dit soort zaken als alternatief voor de schadestatprocedure bij wet een Shadeafwiklelingsumentu Consinentevzaken in het leven te roepen. ${ }^{5}$ Samenstelling. als voorzitter cen uitgeleende" overheidsrechter met feeling woor consumentenzaken, een jurist aangewezen door de schadeplichtige (techts)persoon en en jurist angewezen door en consumentenorganisatie. Deze samenstelling doet denken aan die van de actoren die in de rechtszaal bij een schikkingscomparitie aanwezig zijn. Dat is geen toewal. Het doel van het voorgestelde bureau is immers om op en informele wijze de schadeclains af te wikkelen - in het overgrote decl wan de gewallen zal exn schikking te realiseren zün.

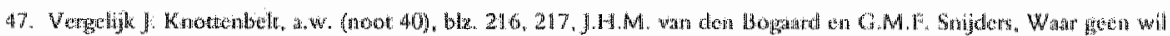

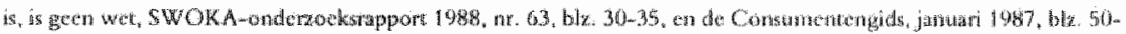
$52:$



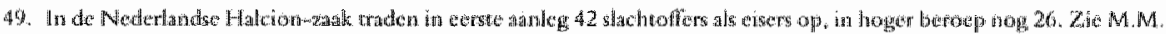



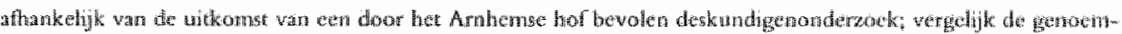



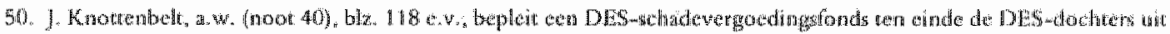

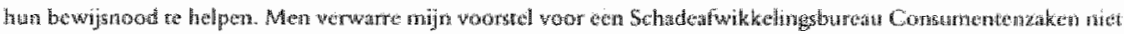

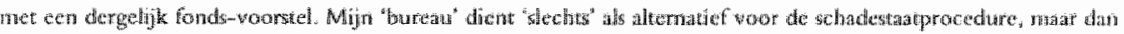




Voor zover informele afdoenug niet mogeligk is ${ }^{53}$, dienen de eisers te worden doorverwezen nat de owerheidsecher. De kosten wa het bureau denen voomamilijk te worden gedragen door de schadeplichtige. Dir idee behoeft uiteraard nadere uitwerking. Indien de "politick' serieuze belangstelling roont, ben ilk gaame bereid een voonstel voor een desbetreffend wetwoorstel met toehchting op te stellen.

Een ardig neveneffect van het loskoppelen van de aansprakeljkheidswaag en de schadeafwikkeling ligkt mij te zijn, dat dan des te cerder als cen wenselijke arapak zal worden beschouwd, dat cen verklaring-voor-rech-procedure betrefende de ansprakelijkheidsvragg wordt gevoerd door een consunentenorganisatie. Voor de beantwoording wan alleen die vraag is het niet nodig dat een hele groep consumenten als cisers in rechte optreedt. Ook dàt is doelmatig consumentenrecht. ${ }^{5.4}$

\section{EEN TERUCTR EDEMWE OVERHEID: KOMEN DE GRENZEN VAM DE CONSUMENTENBSSCHER- MING IN ZICHT?}

De afgelopen maanden zijn we diverse keren opgeschrikt door berichten in de krant, die er samengewat op neer komen dat de overheid woortaan minder aandacht voor consumentenzaken aan de dag zal leggen. Een terugtredende overheid dus.

Zo lat de EG-commissaris voor consumentenzaken antekenen dat de burgers nog we weinig vertrouwen hebben in Europa. Hij wijt dat woor een deel an de regeringen "die wel veel aandacht besteden aan het bedrijsllewen, maar die de zak wan de consument teved als en bijkomstigheid behandelen". ${ }^{35}$

De Raad van ministers van Financien, onder voorzitterschap van Nederland, heeft het budget voor consumentenzaken verlaagd van 25 miljoen naar 10 miljoen gulden. Verschillende Lid-Staten, Nederland voorop, liggen dwars bij de totsandkoming wan de concept-richtlijnen voor produktweiligheid en oneerlijke bedingen in consumentenovereenkomsten. Daamaast dreigt Nederland de paragraaf voor consumentenaangelegenladen te schrappen uit exn ontwerp voor de herzening van het Verdrag van Rone, warin zou worden gestreefd nar een voor de consument "hoog beschermingsiveat. Het toch al schamele budget voor consumentenzaken bijna

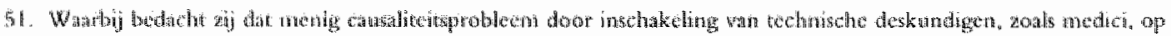

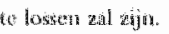

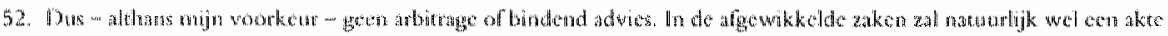

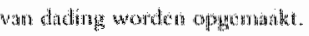

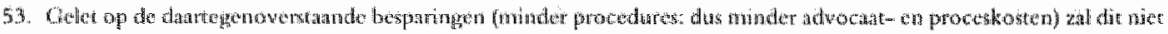



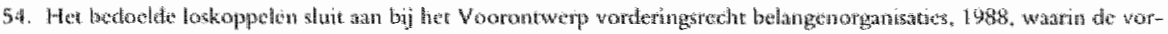

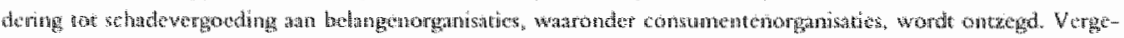

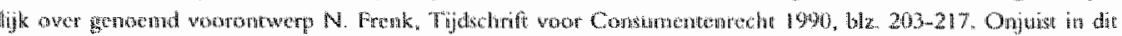

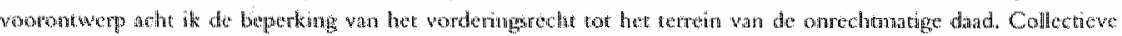

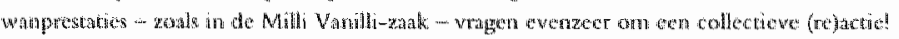

55. 19e Limberger, 26 juli 1991 
éen promille wan de totale EG-begroting) wordt verlaagd. De consument wordt in de EG-begroting voorlopig sluitpost. Jim Murray, directeur van het BEUC (Bureau Européen des Unions de Consommateurs) noemt dit Europese besurit "rampzalig". Op bet Nederlandse Ministerie van Economische Zaken vindt un her kader van de "grote efficiëncy-operatie" en van de 'tussenbalans' een reorganisatie plaats. Minder arbeidsplaatsen dus. Naast enige andere activiteiten valt het consumentembeleid ten prooi aan deze bezuinigingsronde. $5 \%$

Hoe moeten wij deze terugtred van de Europese en Nederlandse overheid waarderen? Komen de grenzen van de consumentenbescherming in zicht? Is deze terugtred "rampzalig', zoals Jim Murray liet aantekenen?

Ik zou deze terugtred van de overheid veeleer willen bestempelen als kortzichtig en dus van korte dunr. Het is een illusie te denken dat een verdere uitbouw van het consumentenrecht een halt kan worden toegeroepen. We moeten ons het volgende goed realiseren.

a. Het begrip "consument' is inmiddels een juridisch begrip geworden. Denk an de wettelijke bescherming dic de consument is toegekend in bij voorbeeld het consum mentenkooprecht (titel 7.1 NBW), het algemene voorwaarden-recht (afd. 6.5.3 NBW) en het produktenaansprakelijkheidsrecht (art. 1407a e.v. BW/afd. 6.3.3 NBW). Alleen al deze voorbeelden bestrijken nagenoeg het gehele contractenrecht en een voor consumenten belangrijk deel van het onrechtmatige daadsrecht. Het enkele fieit nu dat de wetgever op deze terreinen uitspreekt dat dle consument beschermo dient te worden, zal ons rechisdenken mogen en moeten beìnvloeden in alle zaken warin een consument partij is en warin hij rechtens in de verdrukking dreigt te geraken. De wetgever legitimeert de rechter in consumentenzaken te denken in termen van consumentenbescherming. Dit lat zich ten minste vertalen in een in cassatie afdwingbare motiveringsplicht van de rechter.

Een aardig voorbeeld van consumentenbescherming door de rechter buiten een consumentenwettelijk kader vind ik de uitspraak van het Gerechtshof Arnhem in de geruchtmakende Halcion-zaak. sat

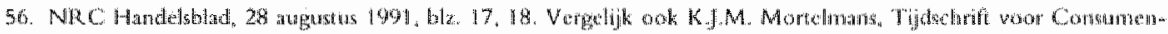

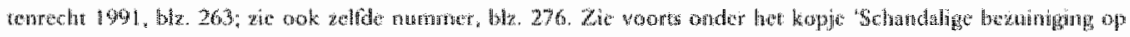

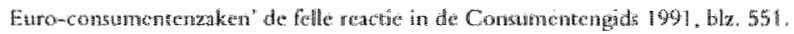

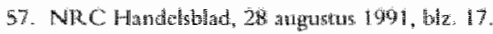

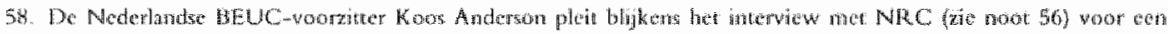

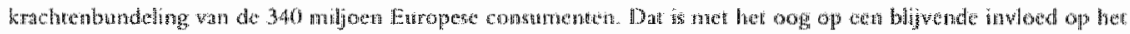

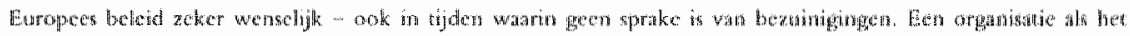

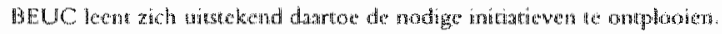

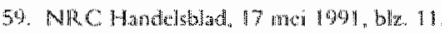

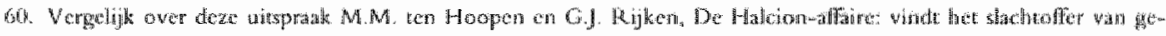

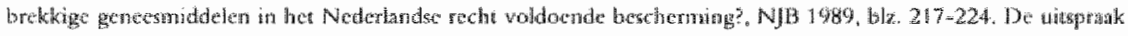



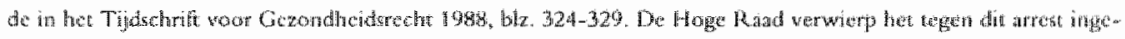


Anders dan de Ambemse rechtbank ${ }^{61}$ heef het Arnhemse hof in deze zaak op voorbeeldige wijze laten zien dat slachtoffers van Halcion ook in een op art. $1401 \mathrm{BWW}$ gebaseerde procedure de gewenste bescherming kan worden geboden. Ten tijde van de uitspraak van genoenind hof was in ons land de wettelijke regeling van de produktenaansprakelijkheid nog wiet wan kracht. ${ }^{2}$ Het Arnhemse hof anticipeerde evenmin inhoudelijk op de EEG-richrlijn produktenaansprakelijkheid, maar liet zich wel door deze regeling inspireren. ${ }^{3}$

b. Indien een wettelijke regeling ontbreekt, lopen ondernemers risico's die - eigen aan rechterlijke uitspraken - niet te voorzien en te overzien zijn. Een verstandig ondernemer wenst geen risico's te lopen, maar wenst deze te beheersen. Hèt instrument daartoe is wetgeving. Wetgeving geeft immers de mogelijkheid van aansprakelijkheidsbeperking. Denk bij voorbeeld aan de verweermiddelen en de korte verjarings - en vervaltermijn in de wettelijke regeling van de produktenaansprakelijkheid (art. 6:185 lid 1 resp. art. 6:191 NBW), alsmede aan de beperkte wettelijke exoneratie voor de verkoper inzake 'produktschade' (art. 7:24 lid 2 NBW).

c. Ondernemers zullen in de komende jaren moeten ervaren dat een groot deel van de algemene voorwatarden die zij in overeenkomsten met consumenten gebruiken, onderuit gehaalld worden ${ }^{\text {si }}$ Deze ervaring zal juist ook bij ondernemers in verband met het hierboven sub b gestelde de roep om wetgeving - consumentenwetgeving dus- doen toenemen. Ook zij zullen een terugtredende overheid tot de orde roepen. Bovendien: meer en meer komen ondernemers tot het inzicht dat het uit marketingoverwegingen bepaald gewenst is om het consumentenbelang als deel van het ondernemersbelang te beschouwen. Het denken in termen als "garantie tot aan de deur" is nitet meer van deze tijd. ${ }^{\prime \prime}$

d. Op Europees niveau doet zich in het bijzonder het probleem voor dat de met het oog op een interne markt zo gewenste harmonisatic van wetgeving van de Lid-Staten in geval van een terugtredende EG-wetgever niet wordt gerealiseerd. In bij voorbeeld de considerans bij het voorstel voor een richtlijn inzake oneerlijke bedingen in consumentenovereenkomsten ${ }^{\text {*is }}$ wordt uitvoerig ingegaan op de grote verschillen in wetge-

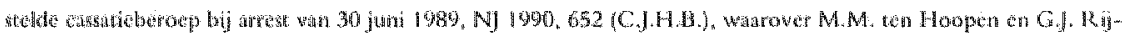

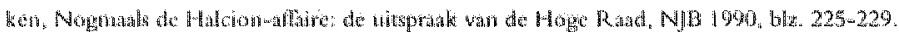

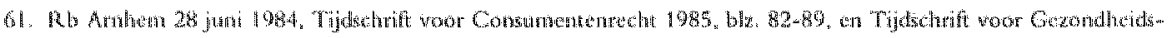

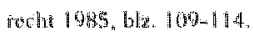

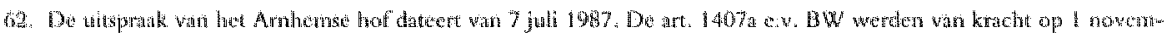
bers 1900 .

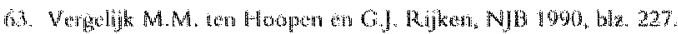

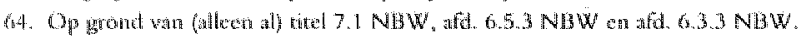

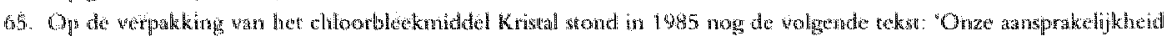

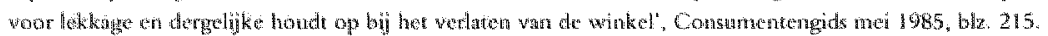

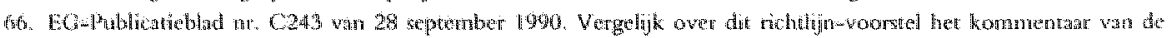
Consumenten Comnasio woor Europa, Ben Hage, december 1990. 
ving in de Lid-Staten op het terrein van de contractsoorwarden Enkele Lid-Staten kenuen op dit terrein zelfs geen enkele adequate wetgeving. In bedodde considerans wordt nadrukkeljk aandacht besteed an een wisprak van het Bwhergenthwof van 20 januari 1983 inzake Lufthansa/Verbraucherschutzverein.6. De Duitse hoogste rechter kwam in die zalk tot het oordeel dat exn antal bedingen in de algemene vervoervoorwarden van Lufthansa, waronder een ansprakelikheidshimet in strijd is met het AGB-Geseiz. Het feit dat deze bedingen in de algemene voomaaten wan Lufthansa identiek zijn aan de IATA-voorwaarden en zels berusten op her Vording van Warschau, laat - aldus lyet BGH - onverlet dat sprake is van algemene woorwatrden in de zin van het AGB-Gesetz. Het BGH acht het nationale belang van een effectieve Dutse consumentenbescherning groter dan het belang wan een interuationale enwormige regelgeving. Resultat hervan is dat cen consument die in Duitshand onder toepassing van Duits recht een wiegreis boekt natr Mallorca een anmerkelijk betere bescherming geniet dan consumenten uit de andere Lid-Staten onder de warking van hum nationale recht. De Europese Commissic acht dit met het oog op de komende genneenschappelike markt terecht een onaanvardbare situatie.

Ik werwacht dan ook niet dat de eerder genoende bezuinigingen zullen leiden tot een dramatische vermindering van nieuwe regelgeving ter bescheming van de consument. Indien de overheid wordt bestookt - zij het wit verschillende motieven - door zowel consumenten- als ondernemersorganisaties, gat zij wel overstag en op EG-niweau moet de overheid in verband met de beoogde hamoniatie wel op de ingeslagen weg voortgan. Korton: het proces in de richting van meer consumentenbeschemende regelgeving is miet meer te stoppen.

\section{HET CONSUMENTENRECHT IN DE JAREN NEGENTG: DE EFFECTERUNGSFASE}

We hebben gezien dat het juridische evenwicht tussen ondernemen en consument onder de werking wan het Burgerlijk Wetboek wan 1838 emstig is verstoord ten nade-



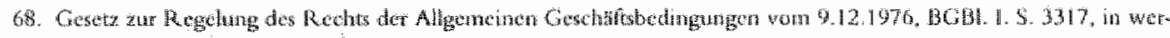

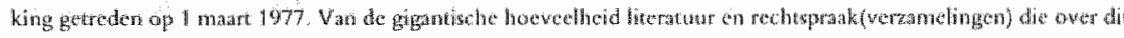



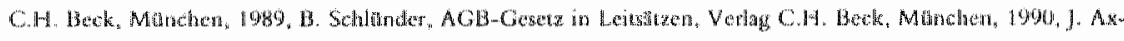

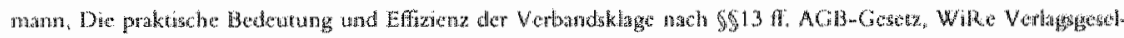

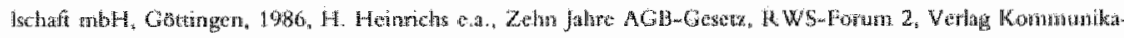







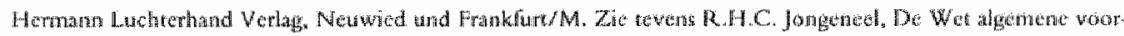

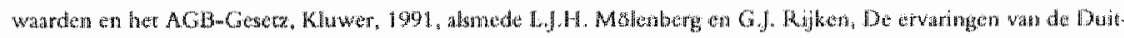




le van de conswinent. Zie hierboven paragrat 3. Ten einde bedoeld evenwich te hertellen, worden weten ingevoend ter beschermug wan de consument. Als blikvanger geldt hot tio produktmantprakelikheid (trgevoerd op 1 november 1990), consumentenkop (in te woren op 1 januari 1992) en algemene voonwarden (everecus in te voercn op 1 jaruari 1992 . vergelijk paragraf 4 . Is de consumentenbescheming die de wetgever anreikt met de inwoering van deze en andere consumentenwetgeving een feit geworden? Zullen ondernemers zol in de jaren negentig gedragen conform de regels wan het dwingendrechitelike consumentenrecht? $\mathrm{k}$ ben datar nogal pessimistisch ower. Regelmatig tref ik in seges algemene huvwoorwarden (hut van woonrumte) bedingen aan die zonder neer in strijd zijn met de in 1979 ingewoerde dwingendrechteljke bepalingen wan de hum van woonrumte (art. 1623 a e.y. $B W$ ). Zo bij voorbeeld het beding warin in strijd met art. $1623 \mathrm{n}$ leden 1 en 4 BW de verhumder zich zelf de bevoegdheid toekent de huarovereenkomst te ontbinden. Met de meuwe consumentenwergeving zal het niet veel anders gan. Kijk bij voorbeld natr de gang van zaken in Duitsland, watr ondememers toch al jaren gewend zijn an een redelijk hoog niveau van consumentenbescheming.

Op 1 aprill 1977 is in Duitsland het $A C B$-Cesez in werking getreden Zelfs nu-14 jaar later - hebben in Duitsland zes juristen van consumentenorganisaties er een dagtak a an - meestal evidente - wetsovertredingen op het terrein van de algemane voorwaarden te keren. In de wandelgangen wordt wel gezegd dat een team van circa 30 full-time juristen nodig zou zijn om het algemene voorwarden-veld te bestrijken. Voor het gehele terein van het consumentenrecht geldt min of meen hetgeen Fritz A. Bultmann, directeur wan de Verbraucherschutzverein e. V. te Berlijn, op een onderzoeksdag consumentenrecht in Mastricht opmerkte:

"Der Satz: "Unllawterer Wesbeuevb Lhmt sich unmer" gilt unverändert. Alle Maßnahmen des Verbraucherschutzvereins sind nur Reaktionen, die für die betroffenen Fimen keine Folgen haben, wenn sie auf Abmahnung oder sonst schriftiche Aufordenng ihr unlauteres und gesetzwidriges Verhalten sofort einstellen. Bis za diesem Zeitpunkt hat das unlautere Verhalien meise genug Vouteile gebracht. ${ }^{\text {pa }}$

Kortom: net de invocring van consumentenbeschemende wetgeving zijn we er niet. Consumentenbescheming moet afgedwongen worder. Comsumentenwetgeving heeft de warde dat er wat afgedwongen kan worden. We zinten in de jaren negen-



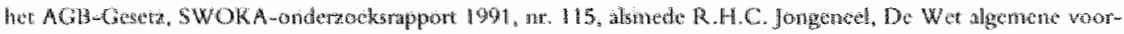

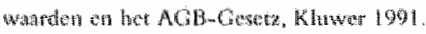

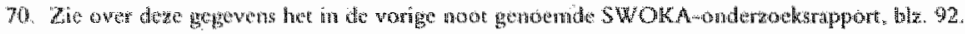

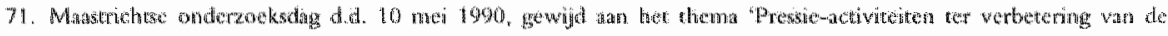

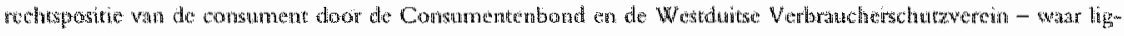
Hen de grenz:m? 
tig dus in de effectueringsase. De vrang njist dan: Whe effectuert, ofwel: Wie bescherm de consinuent?

\subsection{WAT KAN DE CONSUMENT ERMEE?}

Zou de consument zelf in stat zijn de wetteljke bescherming te eftecturen? $U$ mot zich eens de volgende casus voorstellen.

$U$ wilt de hele maand angustus mer vakantio. $U$ besluat tot het maken van en trektocht door Europa met een zogenoemde camper (een 'huis op wielen'). Begin juli zoekt u bij een verhurbedrijf een cariper wit. Een hutroontract wordt opgesteld. Huurperiode augustus. Huurprijs $f$ 4.000, - Aabetaling $f 500$, Betaling restanthuuprijs op 31 juli bij het afhalen van de camper. De humroorwarden worden u ter plekke ter hand gesteld (conform de informatieplicht als bedoeld in art. 6.233 aanhef en sub b jo art. 6:234 NBW). U leest deze huurvoorwarden door. U stut op en prijsverhogingsbeding, warin u met zoved woorden de bevoegdheid wordt ontzegd om de overeenkomst in geval van een prijswerhoging te ontbinden. $U$ weet dat dit beding 'zwart' is (art. $6: 236$ sub i NBW). U zegt tegen uw partner dat u dit beding zou kumen en zou willen vernietigen. Uww partmer - "mak nou geen problemen" weet u daarvan te weerhouden.

Op 31 juli haalt $u$ de camper af. De faktour vermeldt een bedrag van $f 3.900,-$ als restant-humprijs. Een prijsverhoging van $f 400$,- U protestert. De verhuurder doet een beroep op het prijsverhogingsbeding in de huurvoorwaarden. U vernietigt dit beding en legt de verschuldigde 13.500 ,- op tafel. Denkt u dat thet redt? Vergeet her maar! ${ }^{12}$ Aangemoedigd door uw partner-die terecht veest dat de vakantie niet doorgat - betalt u ook de verhoging van $f 400,-$. Na veel aandringen krijgt u gedaan dat op de faktuur de woorden 'onder protest' aangetekend worden. U hebt $f 400,-$ on verschuldigd betaald. U zou deze - na terugkeer van vakantie - kunnen terugvorderen. Begint u een procedure bij de kantonrechter? In verband met de mogelijkheid dat een dergelijke procedure u enige verlofdagen kost, alsmedo in verband met de hange duur van ex procedure en de cmotionele aspecten van het procederen, doet u dat naturulyk niet. Aan de mogelijkheid om uw geschil voor te leggen an en gescliblencommissic behoeft u al helemal niet te denken, ondat w werhuturder niet bij wen branche-organisatie is angesloten en deze u aanstonds mededeelt daaraan niet te zullen medewerken. Finde van het verthat: u neemt uw verlies van $f 400,-$

Op elk voobeeld valt het nodige af te dingen. Zo ook hier. Wat de consument betreft is de werkelikheid nog veel triester: welke consument leest voordat de ondernemer er en beroep op doet de algemene voorwarden door? En: welke consument weet welke bedingen hij op welke grond kan vernietigen? Toch bijna nemand! Ook cen nuancering wat de rol wan de ondememer betreft. We zullen in de konende ja-

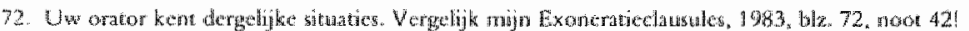


ren hets well whernemers tegenkomen voor wie een 'tewedten klant' exn belangrijk gegewen wornt: Ondernemersorganisatiew zullen datroe hun leden wegwis moeten maken in het nicuwe consumenterurecht. Men dienaagande overigens in het allgemeen niet bijzonder optimistisch.

Ile veres dan ook dat de individuele consument - uiteonderingen dargelaten - net bij machte zal zin de door de wetgever beoogde consumentenbescheming te effecturen: Wat de individuele consument niet kan, kan wellicht zin organisarie. La-

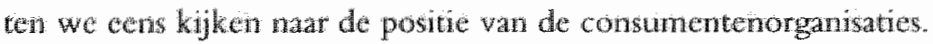

\subsection{CONSUMARTEWHOSHERMING TE EFECTUEREN DOOR CONSUMENTENORGANISATIES}

Consumentenbescherming zal inderdaad voomamelyk door de consumentenorganisates moeten worden afgedwongen. Denk even terug an het voorbeeld wan de verhuurder. Wat in dic casus zou noten gebenten, is dat het prijswerhogingseding uit de algemene voorwarden wordt 'gelicht". Dan bent $u$ - als consument in onze casus - ervan werzekerd dat de overeengekomen prijs niet wordt verhoogd. Wenselijk is dus: een verbod van gebruik. Tot het instellen wan een dergelijke wordering bent niet u bevoegd, mat uw consumentenorganisatie. Aan consumentenorganisatios is in de Wet algemene voorwarden het collectief actierecht gegeven (art. 6:240 (.). NBW). Uw consumentenorganisatic kan onze verhuurder voor het Hagse hof dagvaarden warbij wordt gevorderd a. het bewuste prijsverhogingsbeding onredelijk berwarend te verklaren (art. 6:240 lid $1 \mathrm{NBW}$ ) en b. an de uitspraak van het hof een verbod van gebruik van dat beding (art. 6:241 lid 3 sub a NBW) met een dwangsom (art. 611 a a.v. Rv en art. 6.241 lid $5 \mathrm{NBW}$ ) te verbinden. Het grote voordeel van een rechterlijk verbod wow gebtuk is dat ook andere consumenten daarvan profiteren. ${ }^{24}$

Het kan nog beter. Stel dat onze verhuurder well is aangesloten bij en branche-organisatie die het gebruik van (onredelijk bezwarende bedingen in) algemene voorwarden aan har leden aanbeveelt. In dat geval kan een consumentenorganisatic bedoelde collectieve actie instellen tegen deze branche-organisatie met al haar leden als collkctiveit, dus zonder deze leden afzonderlijk te moeten dagvaarden. Naast de onredelijk bezwarend-verklaring (art. 6.240 lid $1 \mathrm{NBW}$ ), kath dan gevorderd wordan een gebod on deze anbewhing te herropen (art. 6:241 lid 3 sub b NBW), met - wederom - wentue ex d wangson. Via deze methode kan in éen procedure - athankelijk wan de organisatiegrad van de ondernemers - veelal een gehele bedrijstak worden 'gezuiverd' wan het gebruik van onredelijk bezwarende bedingen in algemene

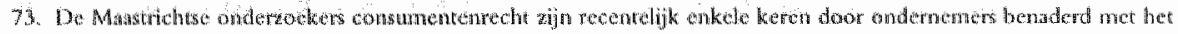

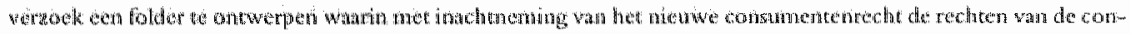



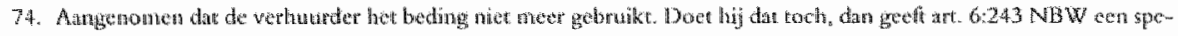
eale wartetigh




voorwaarden. De collectieve actie heeft een groot bereik - "Brewnwikng" zoals onte oosterburen zeggen.

De collective actie ligkt dus het middel om consumentenbescherming te effectuten. Ook buiten het temein van de algemene voorwarden wordt dit in de jaren negentig bet actiemiddel bij uitstek.

\subsection{EER 2 WARE TAAK VOOR CONSUMENTENOR GANISATIES!}

De collectieve actie is dus een geschikt middel om consumentenbeschenting af te dwingen. Echter, met name op het terrein van de algemene voorwanden dreigt dea actiebevoegdheid de consumentenorganisaties woor problemen te stellen, warvan de omvang zich op dit moment nog niet geheel lat overzien. Ik noem de volgende.

\section{a. Duingend conswanentenrecht verplicht ....}

...vooral ook de consumentenorganisaties! De consument zal veel verwachten van de consumentenwetgeving. Er kan nu immers consumentenbescherming afgedwongen worden. Meer dan ooit zullen de schijnwerpers op de consumentenorganisaties gericht zijn. Maken zij wel war wat de metgever de consument belooft?

\section{Genog financiele middelen?}

De consumentenorganisaties zullen veel werk moeten verrichten: voorlichting, advieswerk, bemiddeling, onderhandelen, procederen. Dit alles kost natuurlijk gigan-mtisch veel geld. Hierbij zij bedacht dat onze wetgever - anders dan de Duitse ${ }^{7 \%}$ - de

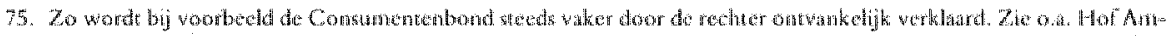

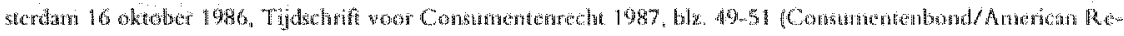





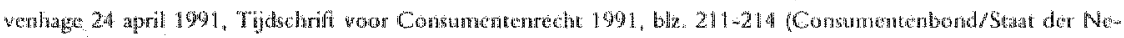

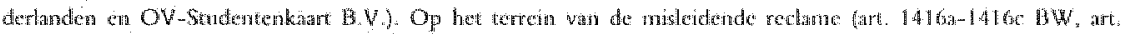

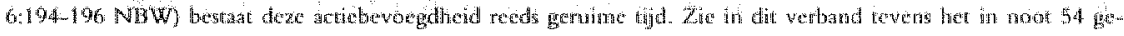

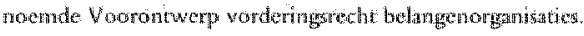

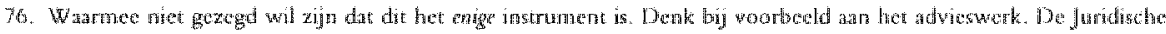

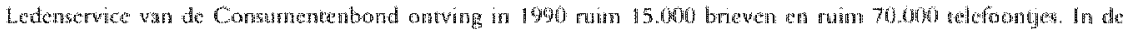

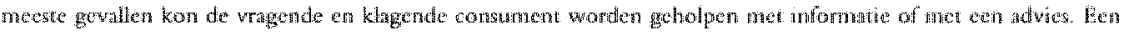

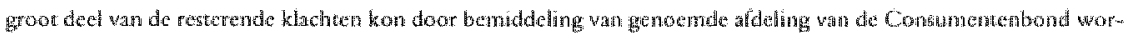

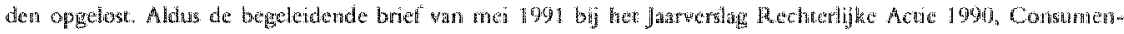
rerribond.

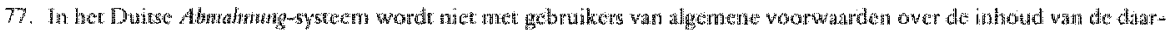

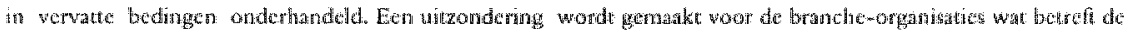


consumentenorganisatios op het terrein wan de algemene woorwarden met een zeer kostbar collecticf actiercht hecf bedacht. Een consumentenorganisatic is mamelyjk niet ontwankelik indien niet blikt dat zij, alvorens de yordering in te stellen, de ondememer c.q. branche-organiatie 'de gellegenheid heef geboden om in onderling overleg de algemene worwarden zodang te wijzigen dat de bezwaren die grond voor de wordering zouden opleveren, zin weggenomen" (ark $6: 240$ lid 4 , eerste wol-

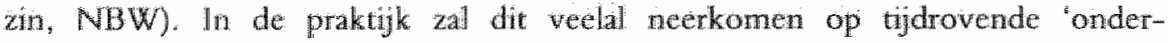
handelingen" ${ }^{4 \%}$, ook al heeft de wetgever een termint van zes manden gesteld (art. 6.240 lid 4, tweede volzin. NBW). In menig geval warin werkeljk serieus wordt onderhandeld, zal de redelijkheid en billijkheid het instellen wan een wordering na het verstrijken vam bedodde zes manden blokkeren. Weliswar zal in bedoeld geval er ook weing behocfe zinn on het Hagse hof te adieren, maar het betekent wel dat zeer weel tijd moet worden gestoken in de 'overleg'-fase. De vragg doemt op of de overheid wel bereid is de nodige financiele middelen te foumeren. De mate van te realiseren consumentenbescherming lijkt op dit terrein mede afhankeljk van de mate van financiering door de overheid.

\section{c. Aanklagersfunctic}

Consumentenorganisaties zullen moeten bepallen weike gebruikers van algemene voorwarden c.q. branche-organisaties angepakt zullen worden. Zij worden geplatst in de positie van een aanklager. Gelet op de enorme omvang van het gebruik van algemene voorwarden zullen prioriteiten moeten worden gesteld. Naar welke criteria? Ageert men alleen tegen grote gebrukers en grote branche-organisaties? Is van belang welke bedrijtstak het betreft? Is het aantal klachten wan consumenten (leden van een organisatie) wan belang? Wat windt de consumentenorganisatic zelf belangrijk? Mogen PR-aspecten een rol spelen? Enzovoorts.

\section{d. Rechlersfuntio}

Consthmentenorganisaties worden op de stoel van de rechter gezet. In de overleg-fase van de art. 6.240 e.v. NBW moeten wij immers angeven of een bepandld beding in bepaalde algemene voorwarden onredelijk bezwarend is. Met betrekking tot de 'zwarte" bedingen (art. 6:236 NBW) lijkt dat simpel. Dat is het niet. Het tal veel in-

\footnotetext{
door dese on

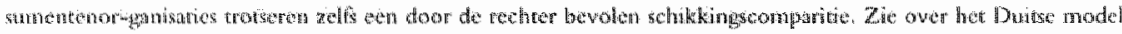





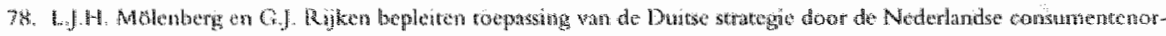

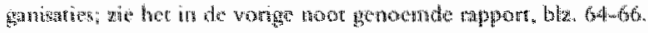


rerpretatieproblenen opleveren. Denk an het woobedd van de dubbeboekngsdausule in het geval van Des Indes warover de Hagge President te oordelon kreng. Blokkert die clausula de nakomingsactie? Dat werd door Des Indes als verwer angevoerd. De President oordeelde van niet. Consumentenorgansaties zullen moeten anticiperen op een mogelyke uitleg door de rechter. Met betrokking tor de "grijze" bedingen (art 6:237 NBW) ligt het welhast nog moeiliker. Wanneer is een cxoneracieclausule (art. 6:237 sub f NBW) onredelijk bezwarend jegens consumenten? In de overleg-fase zal door de consunentenorganisatie toch de beshsing moeten worden genomen of ze met zo cen beding "instemt" (zie art. 6:240 lid 5 NBW). De mate valu consmentenbescherming is darmee mede athankelijk van de beoondeling door consumentenorganisaties.

\section{De leden wan een comsumentenorganisatie}

Het hierboven onder d gestelde legt een zeer zware verantwoordelijkheid op de schouders van de consumentenorganisaties, die zowel extem als intern haar uitwerking niet zal missen. Bij de externe" uitwerking denk ik aan het gegeven dat het oordeel van een consumentenorganisatic ${ }^{3 i}$, dat een bepaald beding in beparlde algemene woorwaarden miet onredelik bezwarend is, zwaar zal neewegen in de oordeelsworming van de rechter in een 'open nom"-procedure (art. 6:233 sub a NBW) wharin een individuele consument - ergens in den lande - stelt dat bedoelld beding onredelik bezwarend is. Stel, dat de rechter ondanks het bedoelde oordeel van de consumentenorganisatie het beding onredelijk bezwarend werklatart op grond van enkelle bijzondere onstandigheden in de voorliggende casus. Dit zou "interne' effecten kunnen hebben: 'hoe leggen we dit aan onze leden uit?"

\section{f. Onderlinge afstentwing conswntenterorganisaties}

Rechters plegen soms een zelfde casus werschillend te beoordelen. Ook consumentenorganisaties - in hun 'rechtersfunctic' (zie sub d) - lopen dat gevaar. Consumontenorganisaties die op het terrein van de algemene voorwaarden actiof worden, zull len moeten bezien hoe dat gevaar te keten. Een verdeling van de "markt"? Inhoudelijke afstemming?

Het is unmiddels genoegzam duidelijk. De collectieve actie is weliswar het mid-

\footnotetext{
79. Zin hicrboven bl\%, 8,9

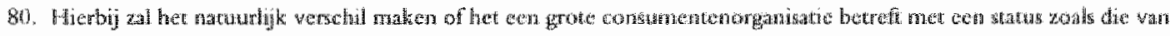

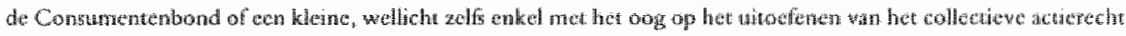

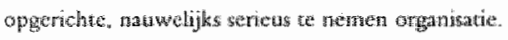


del om consumentenbescheming af te dwingen, doch kent exn antal ingebouwdra handicaps. Voondar een zware taak voor consumentenorganisaties!

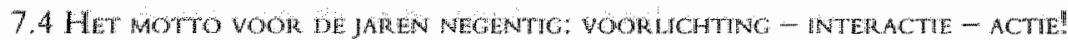

Conumentenbescherming zal als gezegd in de jaren negentig moeten worden afgedwongen. De consument zelf zal dartoe veelal niet in staat zijn. De consumentenbescherming zal voomamelijk door de consumentenorganisaties moeten worden afgedwongen, die daanoe met name de collectiewe actie zullen hanteren. Bij de beslissing wanter het collectrieve acte-middel wordt aangewend, zallen de consumentenorganisaties mede moeten inspelen op de behoefe an consumentenbescherming bij de consument - denk aan de 'aanklagersfunctie' op het terrein van de algemene voorwarden (air paragraf 7.3). Het ligt voor de hand de collectieve actie voonal tegen die ondememers te hanteren, die de meeste en de meest ernstige consumentenklachten veroorzaken. Mitsdien is en voortdurende interactie nodig tussen de consumentenorganisties en de consumenten. Dit vooronderstelt echter dat consumenten weten dat bij voorbeeld een prijsverhoging of een witsluiting van ansprakeljkheid niet altijd toegestaan is. Daartoe is voorlichting nodig. Het motto voor de jaren negentig luidt dan ook: voorlichting - interactic - actict

De consument moet over de riewwe consumentenwetgeving worden voorgelicht. Dit zou primair een tak voor de overheid zajn. In ons land verkeren we in de unieke positie dat een consumentenorganisatie als de Consumentenbond maar liefst circa 630.000 leden heeft. Lees voor leden "huishoudens" en u weet welk enorm bereik de Consumentenbond heef. Met consumentemvoorlichting heeft de Consumentenbond een jatenlange ervaring: in de Consumentengids, de Consumentenreisgids, de Consumentengeldgids, voorlichtingsboekjes en -brochures, optredens in TV-programma's (in 1990 circa 200 keer), in radio-programma's (in 1990 circa 500 keer) en in de dagbladpers ed. (in 1990 circa 10.000 keer), wia de Juridische Ledenservice, enzovoorts. Ik zou muj goed kumen voorstellen dat de Nederlandse overheid haar vootlchtingstak afkoopt door middel wan een stevige fanancisle bijdrage aan de Consumenterbond en andere consumentenorganisuties.

Wij moeten overigens niet de illusie hebben dat het mogelijk zou zijn de consument bij te brengen wat 'het consumentenrecht' inhoudt. Wel is het mogelijk on vereist de consument van eev zodange voorlichting te vooreien dat hij herkent dat er in een bepalde situatic watrin hij verkeert iets mis is". Consumentenvoorlichting moet 'Fallmassig" platswinden, zoals onze oosterburen het uitdrukken." Persoonlijk ben ik byjonder gechameerd van de anpak zoals die te zien is in Duitse TV-uitzendingen

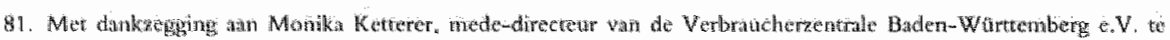

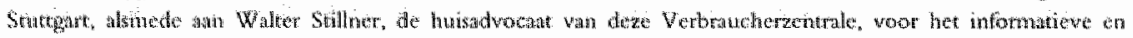
a 
als 'ARD-Ratgeber Recht' en 'WDR-Markt'. In naw oveng met congunen-

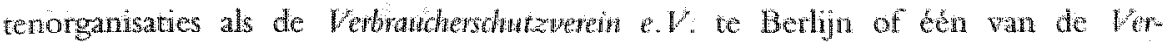

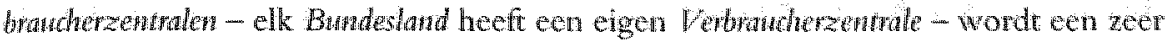
amusant filmpje vertoond over een goed herkerbaar consumentenprobleam. Meest-

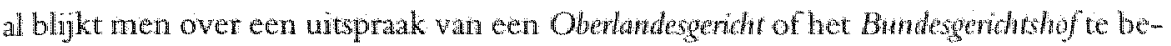
schikken, aan de hand warvan op heldere wijze wordt uiteengezet welke rechten do consument beeft en wat hij in die situatie moet doen. Vedal wordt de consument wor verdere informatie dooverwezen nar een consumentenorganisatio, bij wie hij modelbrieven e.d. kan verknigen. Varzelsprekend leidt dit veelal tot een gigantische run op de consumentenorganisaties, die dan ook goed vootbereid moeter zijn op de verwerking daarvan. Op "Landesebene" wordt wel eens de methode gebruikt. dat via de radio of TV bekend wordt gemaakt dat tegen een bepalalde ondenemer een bepaalde procedure is begonnen. Die bekendmaking levert niet zelden een schat an informatie op, warvan in de procedure gebruik wordt gemakt. De consumentenorganisaties doen van de resultaten van hun actes wederom versag an de consumenten, wardoor dezen zich weer beter voorgehicht weten. 20 komt de interactie als een voortdurend proces op gang.

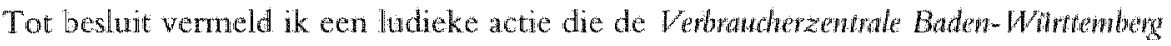
e. $V$. te Stutgart sedert drie jaren hanteert. Een ondernemer in genoemd Bundwhw die het naar de mening van het bestutur van de Verbowderentrale in een bepald jaar wel erg bont heeft gemaakt, krijgt een prijs uitgereikt - niet persoonlijk, mar vià do media - onder de naam 'Die Goldene Nase"; zie de bijlagen 2,3 en 4 bij dete oratie. $U$ begrijpt well dat deze actie de nodige publiciteit oplevert. De advocat van deze Verbrancherzentrale deelde mij desgevraagd mede niet echt bang te zijn woor cen onrechmatige daadsactie zijdens de 'Preisträger' - het is nog steeds geblewen bij een boze brief wan de advocaat van laatstbedoelde.

Onze consumentenorganisaties zou ik een soortgelijke actie niet zonder voorbelhoud durven adviseren. ${ }^{33}$ Wellicht is het op lange temijn zelfs effectiever om ondenemers te belonen - door presentatie aan de pers van een jaarlijkse "top-drie" - voor en naar de mate vart hum consumentwiendelijk handelen.

\section{INBRENG RitikSUNIVERSTET LAMBURO}

De leden van de sectie consumentenrecht van de vakgrocp privatrecht van do Rijksuniversiteit Limburgzullen ook in de komende jaren een bijdrage blijwen leverest an

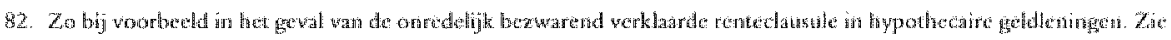
Woot 2 .

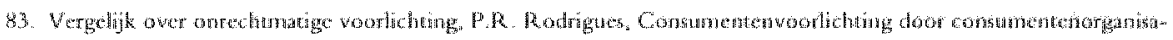

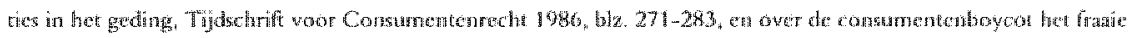

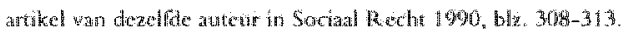


de werdere onwikkling wa het consumentenecht - witerat vooral in de vom wan Wetenschappelike publicatics, zoals dissertaties, tijdschnftartikelen en annotates Per 1 janturi 992 zal de genoemde sectie consumentenrecht naar buten treden onder de neam:

\section{Het lows Verborgh Insitut poor Cowwhontented}

Prof m M.J.P. (lems) Verburgh (1937-1989) geldt als de grondlegger van her Ne-

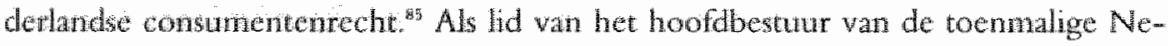
derlandse Constmentenbond heeft lens Verburgh zich onder meer verdiensteljk gemakt door zijn bijdrage an de ontwikkeling wan de afdeling Rechtsbijotand, thans Rechterlijke Akte geheten. Als hoogleraar burgerlik reche aan de Rijksumersiteit Utrecht introduce erde Verburgh hat keuzevak consumentenrecht. Zijn Utrechtse oratio over collectwe acties genet bekendheid in zeer brede kring ${ }^{*}$ De artikelen van Verburgh over het consumentenrech zijh doorspkt met een kritische ondertoon. De Colportagewet ut 1973 oordeelde hij als "niet veel meer dan een fopspeen voor de groot geworden consumentenorganisates" en de branchegeschillemcommisstes vond hij in 1980 '(..) een knisisverschijnsel, ze demonstreren het in gebreke blijven wat de oventeldsechtsprak op dit punt'. Een dergelijke kritische benadering van her consunententecht met het doel een hogere nuate van consumentenbescheming ve bewerkalligen, sprekt de Maastrichtse onderzoekers wel aan. Wij zyn zeer verheugd dat mevouw $\mathrm{N}$. Verburgh-van der Zwan ons toestemming heeft gegeven de naam van lens Verburgh aan ons institute te verbinden.

Eveneens per 1 janwani 1992 zullen enkele Maastrichtsc medewerkers consumentenrecht in het kader wan een samemwerkingsovereenkomst tussen de Consumentenbond en de Rijksuniversiteit Limburg eer forse bijdrage leveren an met name de inhoudelijke toetsing van bedingen in algemene voorwarden.

Consumentenbescherming heeft uiteraard consequenties woor ondernemers. Het consumentenrecht kent bedrifseconomische en markeringaspecten. Samenwerking net de conomische taculteit van onze instrlling ligt dan ook voor de hand. Inmiddels zun - wret de conoom prof. dr. Hans Kasper-enkele onderzockspojecten op-

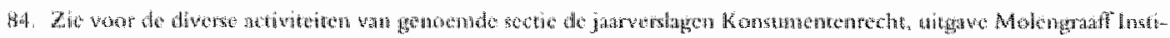

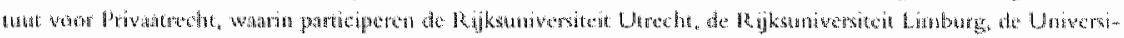

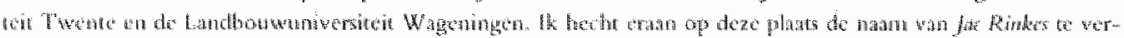

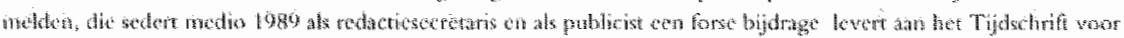

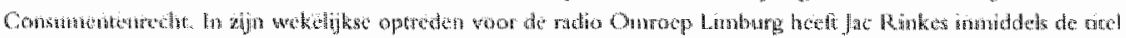

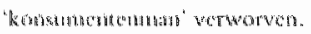



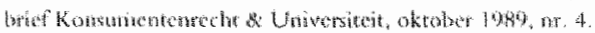

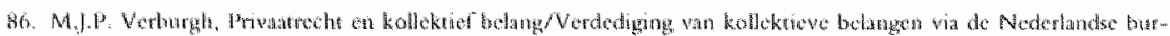

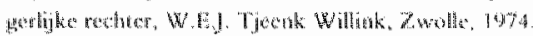

8. Nat $1975,642.1245$.






gezet; warm het consunentenrecht zowel vanit een jundische als eon economische invalshoek wordt benaderd.

In het Mastrichtse onderwij heeft het consumentenecht cen waste plate woworven als keuzeblok, waran jaulijks door circa 40 vierdegars onderwijsconsumenten wet veel enthousiame en goede studieresultaten wordt deelgenomen.

\section{Ton Hestur}

Ik ben aan het einde gekomen van mijn oratio. Het is een goede gewoonto te beduten met ex a antal dankbetuigingen.

\section{Hoofdberturit, Directie en Medewerkers van de Consunentenbond}

Het vestigen van een bijzondere leerstoel consumentenrecht getuigt van een vooruitziende blik. Uw organisate zal in de komende jaren - de effectueringsfase - moeten werken met belangrijke produkten van consumentonwergeving die mede door uw inzet zijn tot stand gebracht. De Nedertandse consumenten -wenk alleen al an ww ruim 630.000 leden - hebben hooggespannen verwachtingen aangande het eftectueren van daadwerkeljke consumentenbescherming. Met deze lecrstoel hebt u ach werzekerd van de steun van wetenschappers die dat doel hoog in hun vaandcl hebben geschreven. Persoonlik erwat ik mijn benoening toc bijzonder hooglewar consumentenrecht alls een enome uidaging. Ik dank u voor het in mij gestelde vertrouwen.

\section{Besfunders van de Rijksmiversteit Limburg}

Gaame dank ik de bestuurders - in het bijzonder Job Cohen - op de divarse niveau's van onze instelling voor hum bijdrage an het realiseren van de vestiging van deze leerstoel en wan mijn benoeming.

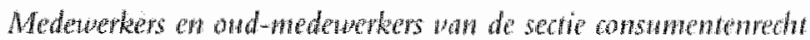

Ik ben mij er goed van bewust dat-materied bezicn - deze leertod voonal ook an jullie inspanaingen op het tertein van het consumententecht is te damken. Ik voel mij an julle zeer venplicht.

\section{Danes on Heren ledef wan de makgrep privaatredi}

Een antall jaren geleden werd door enkelen uwer wewat vecm angekeken togen de consumentenrechtelijke 'cel' binnen onze vakgrocp. Thans is de sectic consumenrenrecht binnen onze wakgrop welhast net zo geacepreerd als delicn wan de consu- 


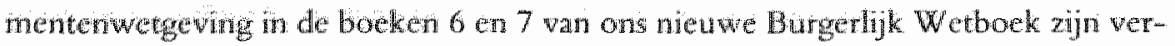
ankerd. Het prettig dat mogen constateren.

\section{Dawes en Heren leden wan de juridische faculteit}

sedert mjn komst in oktober 1984 heb jk met velen van u mogen kennismaken. Dat was doongans en pretige ervaring. Indien wij in bet ond-gouvernement zouden. beschkken over en kantme (grag met goede voorzieningen), dan ontmoet ik daar wellicht ook nog cens een ancall medewerkers die ik thans in de wandelgangen voor werdwalde toersten anzic.

\section{Hoggeachte Hondiss, beste Enowd}

Als promovendus heb ik met een bijzonder groot beslag op jouw tijd gelegd. Toen wij met clkar in contact kwamen, had ik mijn proefschrift al grotendeels afgerond. Dat werd na mijn komst faar Maastricht wel anders. Onze samenwerking werd een zeer intersieve. Voortdurend heb je de Mastrichtse onderzoekers consumentenrecht desevaagd thet rad en daad bijgestaan. De Masutrichtse juridische Gaculteit en de leden wan de sectio constmenterrecht zijn jou veel dank verschuldigd.

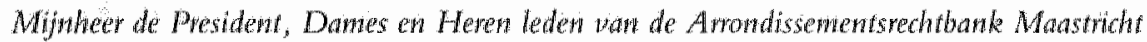

Rum vier jaren was ak als rechter-phatswervanger in uw rechbank actief. Ik heb dat werk net ved plezier gedaan. Bijzonder aardig was dat ik als civilist af en toe in de meervoudige strafkamer mocht meezitten.

Minher de President, Danes en Heren leden van het Gerentshof A when

Sedert twee jaren heb ik als radsheer-plantswervanger een vaste plats in de rweede moervoudige civielo kmer van uw hof Een pleidooien-zitting heeft telkens weer hatr bijzondere charme. Daturnast geeft nij veell voldoening dat u mij toestaat als alIcazithend radsher-commissaris enquetes en comparities af te nemen. Ik ervar het als een vootrecht dat ith in uw midden mag verkeren.

Mijnheer de Rector Magnificus,

Danes an Heren,

lk dank u voor uw andache.

Ik theb gezega. 


\section{BuLAGE 1 .}

\section{Produkionneiligherd}

De Consumentenbond heeft in het kader van de actie "Gewaren-Centrale" onderzocht in hoeverre in de periode april 1982 - april 1985 bij vergelikend warenonder onvelige produkten aam het licht zijn gekomen. Hierbij een bloenlezing van de emstigste gevallen.

\begin{tabular}{|c|c|c|c|}
\hline produkt & $\begin{array}{l}\text { hoever } \\
\text { onder zocht }\end{array}$ & $\begin{array}{l}\text { warvan a } 1 \\
\text { war njet } \\
\text { tataal on } \\
\text { weilig }\end{array}$ & bljzonderheden \\
\hline $\begin{array}{l}\text { gatsor- } \\
\text { ruizen }\end{array}$ & 15 & $\begin{array}{l}3 \times n \mathbb{1} \\
5 \times n n^{2}\end{array}$ & $\begin{array}{l}\text { 9. produceerden te veed koolmonoxide } \\
\text { 2. knoppen en handgreper wewden te } \\
\text { heet }\end{array}$ \\
\hline $\begin{array}{l}\text { vioeiba- } \\
\text { me zoet- } \\
\text { stofrer }\end{array}$ & 5 & 5 & $\begin{array}{l}\text { 1. alle zoetstoken bewatten saechari- } \\
\text { me en cyclamate } \\
\text { 2. produkt niet goed te doseren }\end{array}$ \\
\hline $\begin{array}{l}\text { exend- } \\
\text { gche } \\
\text { gras- } \\
\text { maners }\end{array}$ & 11 & $\|$ & $\begin{array}{l}\text { alle onderzochte merken orvelilg bil } \\
\text { gebruik. Reden: te weindg atsohurming } \\
\text { snijmessen machines lopen te lang } \\
\text { door nadat de motor is argezet }\end{array}$ \\
\hline $\begin{array}{l}\text { tafe } 1- \\
\text { mode1- } \\
\text { kolkas- } \\
\operatorname{ten}\end{array}$ & 60 & 10 & $\begin{array}{l}\text { voornameilik elektrigoh onweilig: } \\
\text { beschadiging bediding }\end{array}$ \\
\hline $\begin{array}{l}\text { elektrin- } \\
\text { sche } \\
\text { kachels }\end{array}$ & 32 & $\begin{array}{rrrr}7 & x & \text { n } x & 1 \\
10 & x & \text { n } & 2\end{array}$ & 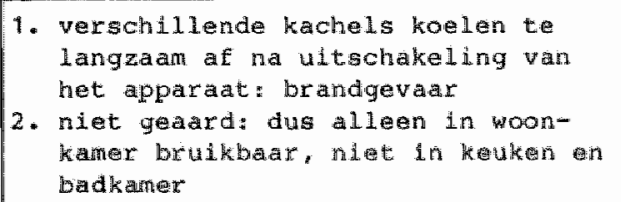 \\
\hline $\begin{array}{l}\text { wasauto- } \\
\text { maten }\end{array}$ & 21 & 2 & $\begin{array}{l}\text { tekortkomingen in de elektriche } \\
\text { isolatio arding onvoldonde }\end{array}$ \\
\hline $\begin{array}{l}\text { Hinder- } \\
\text { fietsi- } \\
\text { zitjes }\end{array}$ & 31 & 7 & 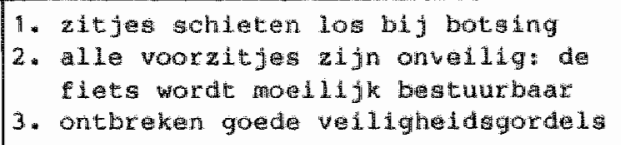 \\
\hline $\begin{array}{l}\text { Kindex } \\
\text { zitjes } \\
\text { in de } \\
\text { atuto }\end{array}$ & 25 & 8 & 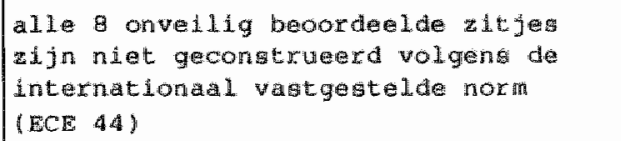 \\
\hline
\end{tabular}




\begin{tabular}{|c|c|c|c|}
\hline produkt & $\begin{array}{l}\text { how } \\
\text { ondered }\end{array}$ & 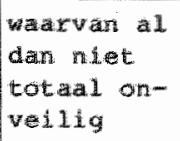 & bujunder hedurer \\
\hline 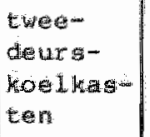 & 24 & 1 & 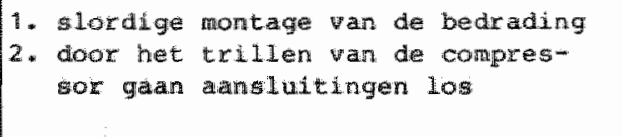 \\
\hline $\begin{array}{l}\text { Kanpex } \\
\text { Kache } 15\end{array}$ & 21 & 10 & $\begin{array}{l}\text { doot onvolledige verbranding kamen } \\
\text { giftige af voergassen wij }\end{array}$ \\
\hline 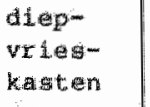 & 20 & 1 & onvelidige bedrading \\
\hline  & 22 & 3 & 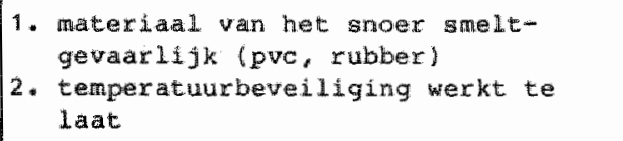 \\
\hline 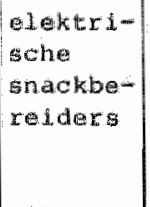 & 19 & 6 &  \\
\hline $\begin{array}{l}\text { cirken- } \\
\text { tugen }\end{array}$ & 18 & 7 & beschermkap ontbreekt \\
\hline $\begin{array}{l}\text { aroogl } \\
\text { tromanels }\end{array}$ & 20 & 2 & $\begin{array}{l}\text { 1. niet voldoende geaard } \\
\text { 2. slechte isolatie }\end{array}$ \\
\hline $\begin{array}{l}\text { verf } \\
\operatorname{sen} x \text { oed }- \\
\text { exs }\end{array}$ & 6 & 2 & $\begin{array}{l}\text { 1. te late automat sche uitschakeling } \\
\text { wanneer luchtinlat geblokkeerd } \\
\text { wordt } \\
\text { 2. slechte temperaturbevedilging }\end{array}$ \\
\hline 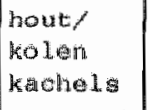 & 15 & $\begin{array}{lll}4 & \times 1 \\
1 & \times 2\end{array}$ & $\begin{array}{l}\text { 1. voordeur afdehting bevat asbest } \\
\text { 2. gevar voor kool-monoxyde vergift- } \\
\text { ging }\end{array}$ \\
\hline 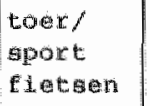 & 15 & 1 & $\begin{array}{l}\text { vorkbretuk/fabrthant zegt toe voor- } \\
\text { taan betere vork te ntomteren }\end{array}$ \\
\hline 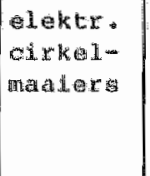 & 11 & 1 &  \\
\hline
\end{tabular}




\begin{tabular}{|c|c|c|c|}
\hline produkt & $\begin{array}{l}\text { hoever } 1 \\
\text { onderzocht }\end{array}$ &  & bijnonder heden \\
\hline $\begin{array}{l}\text { grill- } \\
\text { bakovens }\end{array}$ & 12 & 1 & $\begin{array}{l}\text { Hortagefout . Hel oven komt onder } \\
\text { stroon bij net geard stopontact }\end{array}$ \\
\hline $\begin{array}{l}\text { koffie- } \\
\text { zet } \\
\text { appara- } \\
\text { ten }\end{array}$ & 20 & $\begin{array}{l}1 \times 1 \\
1 \times 2 \\
1 \times 3\end{array}$ & 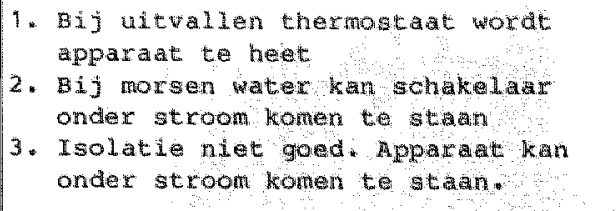 \\
\hline $\begin{array}{l}\text { grate } \\
\text { koel- } \\
\text { kasten }\end{array}$ & 9 & $2 \times 1$ &  \\
\hline $\begin{array}{l}\text { redding } \\
\text { vesten }\end{array}$ & 40 & $\begin{array}{l}2 \times 1 \\
5 \times 2\end{array}$ & 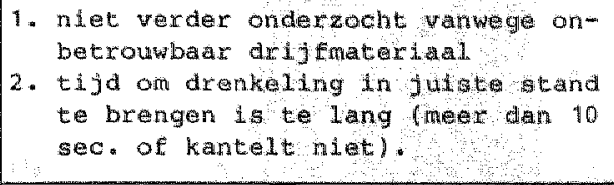 \\
\hline $\begin{array}{l}\text { spaan } \\
\text { plaat }\end{array}$ & 22 & 14 & 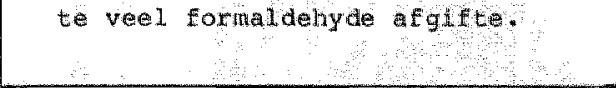 \\
\hline $\begin{array}{l}\text { kinder } \\
\text { Elet } \\
\text { ser }\end{array}$ & 47 & $\begin{array}{l}1 \times 1 \\
1 \times 2\end{array}$ & $\begin{array}{l}\text { 1. sturpen gebroken, trapastagex ud } \\
\text { elkaar gevallen, spatborden age- } \\
\text { broken. } \\
\text { 2. framebreuk, afgebroken spatbord. }\end{array}$ \\
\hline $\begin{array}{l}\text { wandel- } \\
\text { wagens }\end{array}$ & 35 & $\begin{array}{l}4 \times 1 \\
3 \times 2\end{array}$ & $\begin{array}{l}\text { 1. Slechte temwerking } \\
\text { 2. Slechte inklapbeveiliging }\end{array}$ \\
\hline
\end{tabular}




\section{Buyace 2}

\section{Dip Coldene Nase 1989}

Zie onderstand bencht in Die Verbraucherzenung, Januar/Februar 1990.

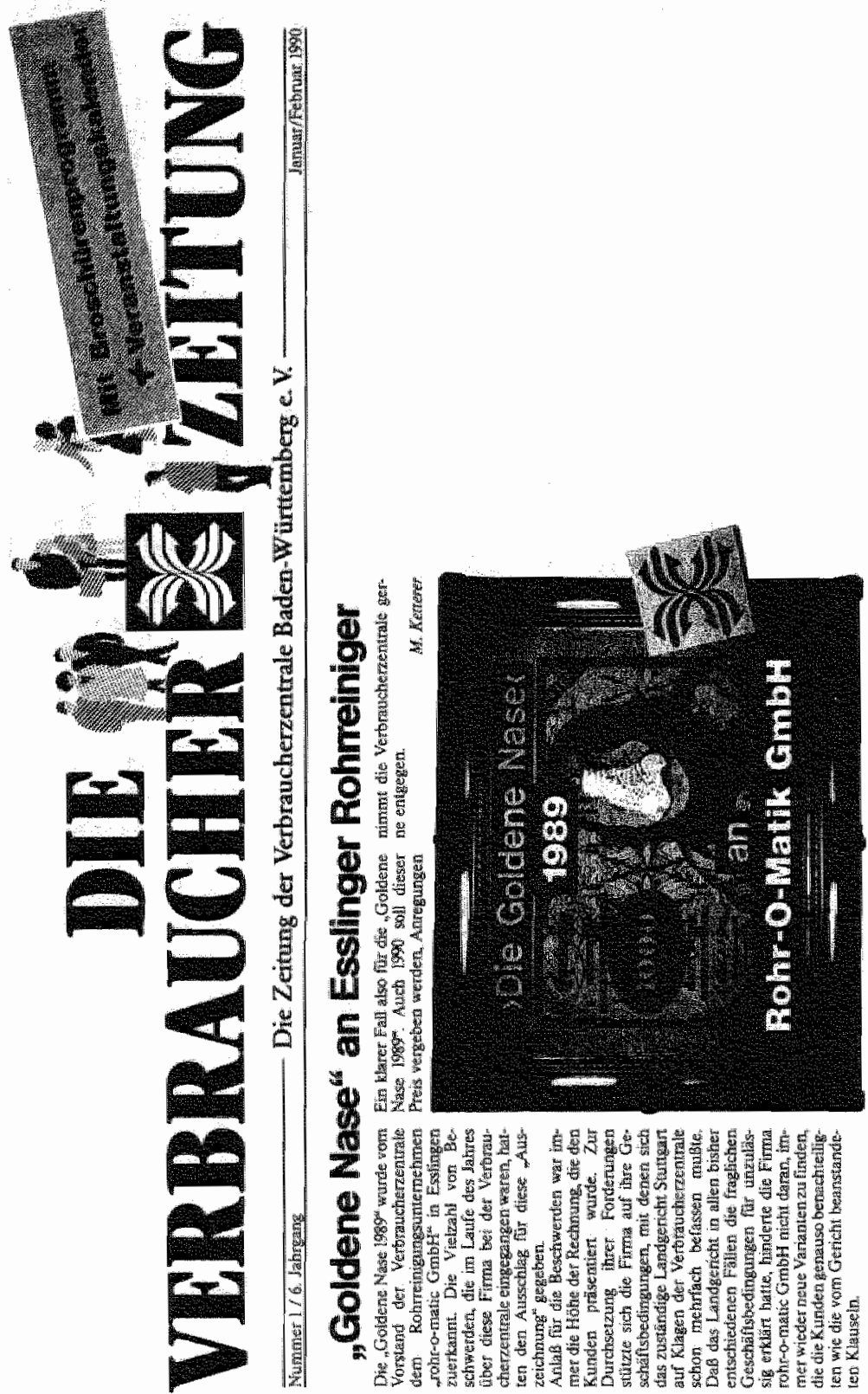


BHLAGE 3

\section{Die Goldene Nase 1990}

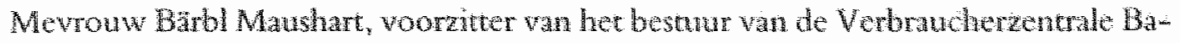
den-Wurttemberg e.V. te Stutgart, toont de "prijs' ana de pers.

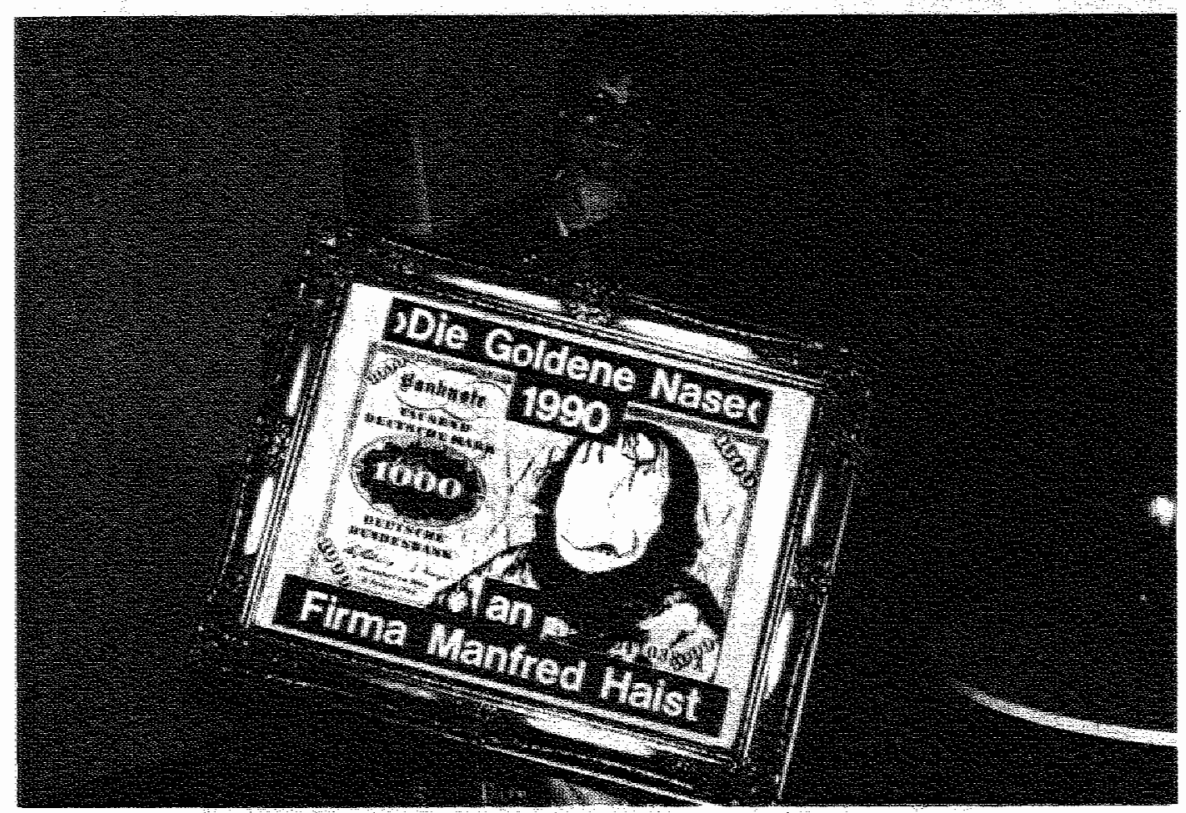


Zie onderstand bethehe in Die Verbraucherzeitung, Januar/Februar 1991

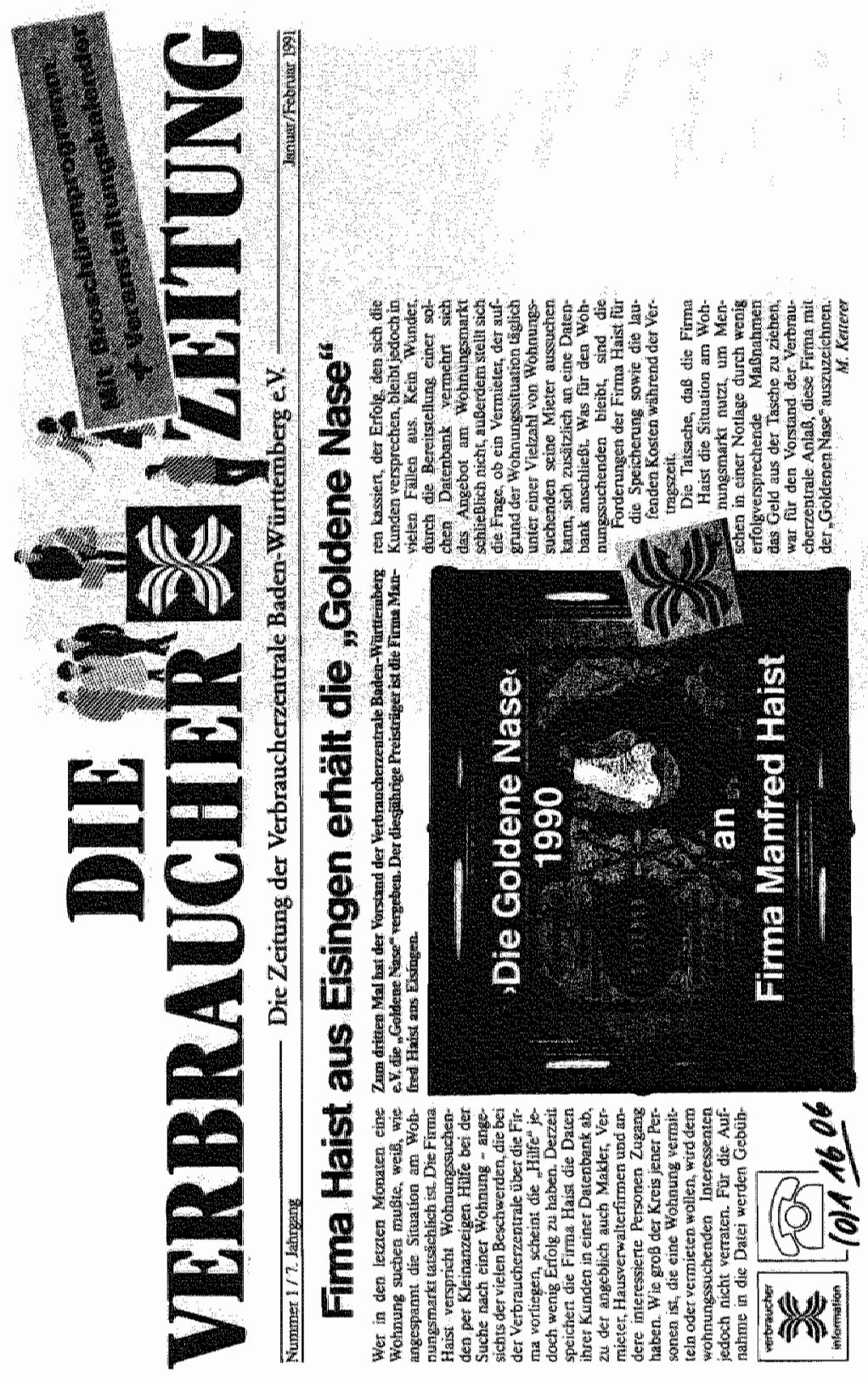

